\title{
The Effect of Universal Health Insurance on Malpractice Claims: The Japanese Experience
}

\section{Citation}

J. Mark Ramseyer, The Effect of Universal Health Insurance on Malpractice Claims: The Japanese Experience, 2 J. Legal Analysis 621 (2010).

\section{Published Version}

http://jla.oxfordjournals.org/content/2/2/621.full.pdf+html

\section{Permanent link}

http://nrs.harvard.edu/urn-3:HUL.InstRepos:30065252

\section{Terms of Use}

This article was downloaded from Harvard University's DASH repository, and is made available under the terms and conditions applicable to Other Posted Material, as set forth at http:// nrs.harvard.edu/urn-3:HUL.InstRepos:dash.current.terms-of-use\#LAA

\section{Share Your Story}

The Harvard community has made this article openly available.

Please share how this access benefits you. Submit a story.

Accessibility 


\title{
THE EFFECT OF UNIVERSAL HEALTH INSURANCE ON MALPRACTICE CLAIMS: THE JAPANESE EXPERIENCE
}

\author{
By J. Mark Ramseyer ${ }^{7}$
}

\begin{abstract}
Japanese patients file relatively few medical malpractice claims. Most scholars try to explain this phenomenon by identifying "faults" in the Japanese judicial system. Largely, the faults they identify do not exist. Instead, a substantial part of the reason for the malpractice claiming patterns may lie in the national health insurance system. In order to contain the cost of this system, the government suppresses the price it pays for the technologically most sophisticated procedures. Predictably as a result, Japanese doctors have focused instead on more rudimentary care. Yet, for reasons common to many societies, Japanese patients are less apt to sue over rudimentary care. They are more likely to sue over sophisticated care. In part, Japanese patients may bring relatively few malpractice suits because the government has (for reasons of cost) suppressed the volume of the services (namely, highly sophisticated services) that would otherwise generate the most malpractice claims. I explore this issue with a dataset covering all malpractice suits that generated a published district court opinion from 1995 to 2004.
\end{abstract}

Potentially, universal health insurance programs do not just alter the supply and distribution of medical services; potentially, they also shape claiming and litigating behavior in malpractice disputes. After all, the programs reduce the direct cost of medical services to patients. The lower costs boost demand, and-to prevent the drain on the public fisc - the government could (and usually does) respond by suppressing the amounts it pays suppliers.

1 Mitsubishi Professor of Japanese Legal Studies, Harvard University. I benefited from the extensive and thoughtful suggestions of Jennifer Arlen, Albert Choi, Richard Epstein, Eric Feldman, Tom Ginsburg, Mark Grady, John Haley, Robert Leflar, Salil Mehra, William Sage, Masatatsu Sato, Steven Shavell, Frank Upham, the participants at and an anonymous referee for the 2009 Conference on Empirical Legal Studies, and participants in workshops at Eastern Mennonite University, Harvard University, and the University of Tokyo. I received generous financial assistance from Harvard Law School, the University of Tokyo, and the Petrie-Flom Center for Health Law Policy, Biotechnology, and Bioethics at Harvard Law School. 
By cutting the price it pays suppliers, a universal insurance program alters both the quality and the mix of medical services sold. Facing statemandated prices below market-clearing levels, suppliers will cut the quality of the services they provide. But because the program also changes the relative prices of the various medical services, suppliers will shift the mix of services they sell as well. They will offer relatively more of those services commanding the higher mandated prices. They will offer less of those commanding the lower prices.

For malpractice claiming patterns, these changes create potentially cross-cutting effects. On the one hand, all else held equal, as the suppressed prices induce sellers to degrade quality, malpractice claims should rise. On the other hand, as sellers change the mix of services they offer in response to the new price structure, they might—plausibly-shift the mix away from those services that generate the most malpractice claims.

Consider the logic (explained in more detail below). To suppress the potentially exploding costs of its insurance program, suppose a legislature cuts the relative price it pays for the more sophisticated (and expensive) services. Technologically intensive, physically invasive, implemented by a team of medical specialists, and targeted toward high-risk patients, these services often cause more observably adverse events than ordinary primary care. They also generate the most legally cognizable negligence claims. Necessarily, services that generate the most provable negligence and observable "bad outcomes" will generate the most malpractice claims. If the national insurance leads sellers to provide fewer such services, fewer malpractice claims will follow. In this article I explore this dynamic with aggregate data on Japanese malpractice suits and insurance premia, and microlevel data on all Japanese published medical malpractice opinions from 1995 to 2004.

Since the late-1950s, the Japanese government has offered universal health insurance. The program heavily subsidizes the cost of medical services, but does so at rates that poorly compensate the most modern and sophisticated procedures. As a result, Japanese physicians offer large quantities of rudimentary medical services. They offer far less of the sophisticated procedures at the heart of modern medicine. In turn, this dynamic may have led to fewer malpractice claims (I take no position on whether the scarcity of claims is "good" or "bad"). Patients anywhere seldom sue unless they experience an observable "bad outcome." But observably bad outcomes do not as often occur in the rudimentary medicine so common 
in Japan: where physicians work in small settings, do relatively little, and mostly see fundamentally healthy patients. They occur when physicians undertake complicated procedures among a team of medical specialists in large hospitals to save high-risk patients. Because of the skewed reimbursement rates, Japanese doctors perform plenty of the simple procedures and prescribe large quantities of ordinary antibiotics. They offer less of the technologically intensive, complicated, invasive procedures. In part because the latter-not the former-generate the malpractice disputes, Japanese patients bring fewer malpractice claims. ${ }^{2}$

I begin by reviewing some basic comparative statistics on medical malpractice and the secondary literature on malpractice litigation in Japan (Section 1). I offer a brief description of the Japanese health care industry (Section 2). I describe my data and variables, and investigate potential biases (Section 3). Using the data, I then explore the impact of the Japanese national health insurance program on malpractice claims: whom do patients sue and how much do they collect (Section 4), how much claiming occurs (both in- and out-of-court; Section 5), and why are claiming levels as low as they are (Section 6)? Given the very real biases in the dataset, Section 3 is long. Impatient readers may wish to skim ahead to Section 4 , and return to 3 as necessary.

\section{THE LITERATURE}

\subsection{The United States-the Short Story}

We know surprisingly little about medical malpractice disputes in Japan, but we know a good bit about them in the United States. Given the massive amounts of wealth transferred, scholars devote considerable attention to the disputes. Although this is not a study of American malpractice, at least implicitly most readers will compare Japan to what they think they know of the United States. Consider, then, some simple statistics.

In the United States (with its population of 307 million; the Japanese population is 128 million), patients or their heirs file 50,000-160,000 malpractice claims each year. In a careful study, Mello \& Studdert (2006: 13)

2 Granted, simple procedures generate medical malpractice claims too. Even a simple knee operation, after all, can generate a claim if the doctor operates on the wrong knee. And patients do sue non-specialist clinic doctors in Japan. The point here is simply that the more sophisticated and complex procedures are more likely to generate claims-a point consistent with the data from Japan detailed below. 
propose the low end of the range: 50,000 to 60,000 brought-claims annually, for a total transfer of $\$ 5.8$ billion. The AON insurance brokerage firm proposes the high end: 156,000 paid-claims, for a total $\$ 28.7$ billion (AON, 2004). ${ }^{3}$

Within the United States, disputing patterns vary widely by region. Comparisons across studies are difficult, of course, as scholars use widely divergent data sources and employ different definitions. Consider, however, some very simple statistics. From 1990 to 1997, claimants in Florida (with its 14 million population) filed about 2,600 claims (Vidmar, et al., 2005: 333), and collected on 50-60 percent of them. Those in Texas (population 24 million) in 2002 filed 6,929 claims and collected on 5,555 (Black, et al., 2005: 246 tab. 13). At trial, U.S. malpractice claimants prevail perhaps 20-30 percent of the time (Mello \& Studdert, 2006: 13; Sloan \& Chepke, 2008: 165; Bovbjerg \& Bartow, 2003: 32). ${ }^{4}$

When successful, U.S. patients (or heirs) collect $\$ 150,000$ to $\$ 310,000$ each. AON suggests that the average successful claimant collects $\$ 178,000$ (AON, 2004). In Florida, the median successful claimant in 2003 collected $\$ 150,000$ and the mean claimant \$300,000 (Vidmar, et al., 2005: 338 tab. 6). An insurer trade association reported median 2001 payouts of about $\$ 180,000$, and mean payouts of \$310,000 (Bovbjerg \& Bartow, 2003: 27). Mello \& Studdert (2006: 13) estimate the range for 2003 at $\$ 260,000$ to $\$ 310,000$.

In wrongful death claims (25-35 percent of the claims; Vidmar, 2005: 340 ), heirs collect $\$ 200,000$ to $\$ 300,000$. In Florida, they received median payments of $\$ 195,000$ and mean payments of $\$ 290,000$ (1990-2003; Vidmar, et al., 2005: 340 tab. 7). According to the National Practitioner

3 Federal law apparently requires malpractice payments to be reported to the National Practitioner Data Bank. According to the NPDB, however, only 17,000 claims were paid in 2005 in the United States. NPDB 2005.

Robert Leflar estimates the number of claims made (not claims paid) in the United States at 70,000 per year (private correspondence).

4 As Mello \& Studdert (2006: 13) recently put it:

A reasonable estimate [of the number of malpractice claims brought each year] is probably in the 50,000 to 60,000 range. Available figures suggest that approximately 70 percent of malpractice claims do not reach trial. Those that do are heard by a jury.... Plaintiffs prevail in approximately 30 percent of trials. Considering settlements and verdicts together, about 30 percent of all claims are closed with a payment to the plaintiff. 
Data Bank (operated by the Department of Health \& Human Services), in 2005 they collected median payments of $\$ 175,000$ (NPDB 2005).

To protect themselves against these malpractice claims, physicians buy insurance coverage. Premiums vary with the insurance underwriting cycle, location, and specialty. As of 2000, the mean American physician paid a premium of about \$18,500 (Bovbjerg \& Bartow, 2003: 13). In some states doctors pay more-the mean physician in West Virginia paid $\$ 39,050$. And in some specialties they pay more-in orthopedic surgery (not the field with the highest premiums), in 2002 the mean doctor paid $\$ 38,200$ in the United States as a whole. The mean orthopedic surgeon in Pennsylvania paid \$73,300 (Bovbjerg \& Bartow, 2003, 15).

Nonstandardized and complex, malpractice claims take time to unravel. From the time of the accident to its eventual resolution (litigated and settled claims grouped together), claimants in Florida spent about 3.3 years (Vidmar, et al., 2005: 330-331 tabs. 1, 2). In the United States more broadly, according to the National Practitioner Data Bank, they spent a median 4.13 years and a mean 4.66 years (NPDB 2005).

Despite these large numbers of claims, studies of the U.S. malpractice environment find that patients miss much of malpractice (Weiler et al., 1993; Mello \& Studdert, 2006: 16). They filed many claims, but they suffered many more incidents of bad medical practice. They may sue some doctors who did nothing wrong-though most who do apparently lose (Studdert, et al., 2006). But they also miss many eminently negligent practitioners.

\subsection{Japan-the Official Court Data}

The administrative office of the Japanese courts does not disclose much about medical malpractice litigation, but it does specify its basic contours: plaintiffs file few claims in court; of the claims they do file, they drop or settle most; if they litigate to a final judgment, they spend about three years in court; and at that final disposition, they win about 30-40 percent of the time.

In 2004, Japanese plaintiffs filed about 1,100 medical malpractice cases. In the same year, the district courts closed about 1,000 (Table 1 Panel A). Low as these numbers are, they did not represent a decline. Instead, they were nearly twice as large as they had been in 1998. Additional summary statistics appear in Table 2.

The parties litigated about 40 percent of these $1000+$ suits to a final (lower-court) judgment. Plaintiffs filed 632 suits in 1998, and the courts 
Table 1. Selected Summary Statistics (I)

\begin{tabular}{|c|c|c|c|c|}
\hline \multirow{2}{*}{} & \multicolumn{5}{|c|}{ A. Numbers of Decisions } \\
\cline { 2 - 5 } & $\mathbf{( 1 )}$ & $\mathbf{( 2 )}$ & (3) & (4) \\
\cline { 2 - 5 } & $\begin{array}{c}\text { Cases } \\
\text { Filed }\end{array}$ & $\begin{array}{c}\text { Cases } \\
\text { Closed }\end{array}$ & $\begin{array}{c}\text { Court } \\
\text { Decisions }\end{array}$ & $\begin{array}{c}\text { Published } \\
\text { Opinions }\end{array}$ \\
\hline 1995 & & & & 42 \\
\hline 1996 & & & & 44 \\
\hline 1997 & 678 & 569 & 230 & 33 \\
\hline 1998 & 795 & 691 & 305 & 38 \\
\hline 1999 & 824 & 722 & 334 & 48 \\
\hline 2000 & 906 & 869 & 386 & 44 \\
\hline 2001 & 1003 & 1035 & 406 & 30 \\
\hline 2002 & 1110 & 1004 & 405 & 16 \\
\hline 2003 & & & & 232 \\
\hline 2004 & & & & 30 \\
\hline
\end{tabular}

Notes: Columns (1) through ( 3 ) are from the administrative office of the courts; Column (4) is from the published opinion database, as described in the text. Column (3) are hanketsu judgments.

\begin{tabular}{|c|c|c|c|c|}
\hline \multirow{2}{*}{} & \multicolumn{5}{|c|}{ B. Filing-to-Judgment Times and Recovery Rates } \\
\cline { 2 - 5 } & \multicolumn{2}{|c|}{ All Cases } & (2) & \multicolumn{2}{c|}{ Published Opinions } \\
\cline { 2 - 5 } & $\begin{array}{c}\text { Filing to } \\
\text { Judgment }\end{array}$ & $\begin{array}{c}\text { Plaintiff } \\
\text { Recovers }\end{array}$ & $\begin{array}{c}\text { Filing to } \\
\text { Judgment }\end{array}$ & $\begin{array}{c}\text { Plaintiff } \\
\text { Recovers }\end{array}$ \\
\hline 1995 & & & 5.00 yr. & $66.7 \%$ \\
\hline 1996 & & & 3.80 & 65.9 \\
\hline 1997 & & $43.5 \%$ & 4.86 & 60.6 \\
\hline 1998 & 2.93 yr. & 30.4 & 5.00 & 71.1 \\
\hline 1999 & 2.88 & 46.9 & 4.24 & 73.9 \\
\hline 2000 & 2.97 & 38.3 & 3.68 & 75.9 \\
\hline 2001 & 2.72 & 38.6 & 3.55 & 86.7 \\
\hline 2002 & 2.58 & 44.3 & 3.82 & 96.7 \\
\hline 2003 & 2.31 & 39.5 & 3.55 & 93.8 \\
\hline 2004 & 2.28 & & & \\
\hline
\end{tabular}

Notes: Column (2) includes only cases proceeding to judgment (hanketsu); Column (1) includes cases that settle. Columns (1) and (2) are from the administrative office of the courts; Columns (3) and (4) are from the published opinion database, as described in the text. 
Table 1. (Continued)

\begin{tabular}{|l|c|c|c|}
\hline \multirow{4}{*}{} & \multicolumn{4}{|c|}{ C. Principal Litigation Venues } \\
\cline { 2 - 4 } & (1) & (2) & (3) \\
\hline Tokyo'd Med Mal & Ord. Civil Litigation & All Med Mal. \\
\hline Osaka & $30.5 \%$ & 20.5 & $40.6 \%$ \\
\hline Nagoya & 16.4 & 9.4 & 26.5 \\
\hline Yokohama & 4.9 & 4.3 & 5.5 \\
\hline Fukuoka & 4.9 & 3.5 & - \\
\hline Kobe & 4.3 & 9.5 & 8.1 \\
\hline Other & 3.4 & 3.0 & 4.2 \\
\hline
\end{tabular}

Notes: Column (1) is from the published opinion database; Column (2) is from the administrative office of the courts; Column (3) is from Maeda, Sakamoto, \& Nobutomo (2001).

Sources: Published opinion data base, as discussed in the text; Maeda, Sakamoto, \& Nobutomo (2001); Inoue (2007); Saiko saibansho jimusokyoku (2004).

adjudicated 232 (Table 1 Panel A). They filed 1,110 in 2004, and the courts adjudicated 405 (40 percent). In the rest of the cases, either the plaintiffs dropped their claims or the defendants paid out-of-court. These settlement rates track those for civil litigation more generally: the courts closed 149,000 ordinary litigation cases in 2004, but adjudicated only 71,000 of them (48 percent) (Shiho tokei, 2004: tab. 20).

Malpractice claims take longer to adjudicate than the typical civil suit. In 1998, from filing to judgment the courts in malpractice suits took 35 months. ${ }^{5}$ By 2004, they had cut that number to 27 months (Table 1 Panel B). Most civil suits take far less time: of the 71,000 suits adjudicated in 2004, the courts closed 76 percent within one year. They closed 97 percent within three (Shiho tokei, 2004: tab. 20).

Plaintiffs recover damages in about 30-45 percent of the medical malpractice cases they litigate to a final judgment (Table 1 Panel B). ${ }^{6}$ This is lower than the comparable figure for civil litigation more generally. Of the 71,000 ordinary civil suits adjudicated in 2004, plaintiffs won (in whole or in part) 84.1 percent. Of the 44,000 suits in which they demanded

5 Maeda, Sakamoto, \& Nobutomo (2001: 58) find the mean filing-to-judgment times of 3.0 years for 1989-1998.

6 Hagihara, Nishi, \& Nobutomo (2003: 121) find plaintiff recovery rates of 31.8 percent in 1986-1998 malpractice cases. 
Table 2. Selected Summary Statistics (II)

\begin{tabular}{|l|c|c|}
\hline \multicolumn{3}{|c|}{ A. Principal Malpractice Claims, by Procedure } \\
\hline & Pub op & All cases \\
\hline Surgery-related & $46.3 \%$ & 38.9 \\
\hline Obstetrics & 15.5 & 13.7 \\
\hline Cancer & 16.7 & \\
\hline Medication-related & 15.2 & \\
\hline Misdiagnosis & 12.4 & \\
\hline Cerebrovascular & 10.3 & \\
\hline Emergency facilities & 9.8 & \\
\hline Cardiovascular & 7.5 & \\
\hline
\end{tabular}

Notes: Published opinion dataset, as described in text; $n=348$. Categories are not mutually exclusive.

\begin{tabular}{|l|c|c|}
\hline \multirow{2}{*}{} & \multicolumn{2}{|c|}{ B. Malpractice Claims and Beds, by Institution } \\
\cline { 2 - 3 } & Claims & Beds \\
\hline Government hospital & $20.7 \%$ & $21.4 \%$ \\
\hline University hospital & 17.5 & $5.7 \%$ \\
\hline Other public hospital & 17.1 & $17.8 \%$ \\
\hline Private hospital & 22.7 & $55.2 \%{ }^{\star}$ \\
\hline Private clinic & 18.7 & \\
\hline Dental clinic & 1.5 & \\
\hline
\end{tabular}

Notes: Claims data from published opinion dataset, as described in text; $\mathrm{n}=343$.

*: Includes both private hospitals and private clinics.

\begin{tabular}{|c|c|}
\hline \multicolumn{2}{|c|}{ C. Malpractice Claims, by Patient Age } \\
\hline Age & \% Civil Cases \\
\hline $0-2$ & $16.1 \%$ \\
\hline $3-10$ & 4.0 \\
\hline $11-20$ & 6.6 \\
\hline $21-30$ & 12.6 \\
\hline $31-40$ & 7.8 \\
\hline $41-50$ & 10.6 \\
\hline $51-60$ & 16.1 \\
\hline $61-70$ & 10.9 \\
\hline $71-$ & 15.2 \\
\hline
\end{tabular}

Notes: Published opinion dataset, as described in text, $\mathrm{n}=348$.

Sources: Published opinion data base, as described in the text; www.courts.go.jp/saikosai/ about/iinkai/izikankei/toukei_01.html (through_04.html); Kosei rodo sho (2005). 
a money judgment, they recovered some amount in 80.9 percent (Shiho tokei, 2004: tab. 19).

\subsection{Japan-the Scholarship}

Why Japanese patients claim and litigate as they do raises a variety of issues, some general to civil litigation more broadly, and some specific to medical malpractice. ${ }^{7}$ In a careful and perceptive series of studies, legal scholar Robert B. Leflar (2009a: 444-445) focuses on the institutional structure of the courts and the legal services industry. The small number of lawyers (about 24,000), he notes, raises the cost of malpractice litigation. The "delay in case resolution (at least before recent reforms)" reduced its return. The predictability of the damage awards facilitates out-ofcourt settlement (see also Leflar \& Iwata, 2005). And the tendency of Japanese attorneys to demand a non-contingent retainer up-front requires many would-be plaintiffs to front cash they do not have.

By contrast, Hideo Yasunaga (2008: 39-40) of the University of Tokyo Medical Faculty champions cultural explanations. "Japanese people have a tendency to avoid antagonist situations or confrontation," he writes, and prefer "out-of-court settlements for dispute resolutions." Like Leflar, he does note that attorneys are few and delays chronic. But unlike Leflar he characterizes the resulting situation in conspiratorial terms: until the 1990s, the "insidious violations of human rights" in medical practice were "hushed up and concealed."

Legal scholar Eric Feldman (2009: 257-258) sees malpractice litigation as a phenomenon that reflects both "Japanese culture" and structural barriers that "inhibit access to the legal system." According to Feldman (2009: 259), "the government's long-standing approach to tort-related claims ... effectively shut the door to tort litigation." Feldman attributes the low litigation and claiming rates in part to the non-contingent retainer arrangements (264) and the long delays: "in 2006 it still took an average of 25.1 months for the average malpractice case to move from filing to final judgment in the district courts" (269).

7 Ramseyer \& Nakazato (1999: 70-74) suggested that claims were low because there was little quality dispersion in Japanese medicine, and the courts set the standard of care low enough that few doctors failed to meet it. As the discussion below shows, however, there is indeed quality dispersion in Japanese medicine-and plaintiffs disproportionately target the doctors offering the highest quality care. 
Feldman adds two additional structural factors. First, Japanese courts require plaintiffs to "prove the central elements of their allegations" (2009: 263-264). "[B]y requiring plaintiffs to bear the burden of proof in medical malpractice cases," he explains, "Japanese courts effectively limit the number of malpractice claims that can succeed." Second, court awards are not just predictable, but "modest" besides (265). More specifically, "[d]amages in medical malpractice cases in Japan are ... more predictable and more modest than in the United States" (266). By contrast, Leflar \& Iwata (2005) observe that "mean and median awards in U.S. wrongful death cases ... seem not to diverge radically from the Japanese scale of things."

Scholars have discussed several other aspects of the Japanese malpractice disputing environment. Leflar (2009a) and Leflar \& Iwata (2005: 201), for example, suggest that malpractice insurance premiums in Japan "could be considered a very rough-hewn proxy for liability payouts in the long term." They then observe (2009: 8 n.28) that physician members of the Japan Medical Association (JMA) obtain their coverage for 70,000 yen (about $\$ 700$ ), and general hospitals for about 30,000 yen (about \$300) per bed. ${ }^{8}$ Other discussions of the malpractice insurance industry include Nakajima, et al. (2001), Kinoshita (2007), Yamashita (2008), and Miyasaka (2002).

Prosecutors in Japan bring criminal charges against physicians for the most egregious cases of malpractice. Leflar (2009b) and Leflar \& Iwata (2005) carefully explore the possibility that criminal sanctions might fill a gap in incentives left by the scarcity of private litigation. They note that prosecutors bring few claims, but observe that they obtain broad news coverage for the few they do file. Criminal prosecutions for malpractice are also discussed in Sawa (2008).

Two papers examine unpublished as well as published decisions in malpractice cases. Maeda, Sakamoto, \& Nobutomo (2001) study 310 malpractice cases from 1989-1998 in the major district courts (importantly, including Tokyo and Osaka). Like Leflar, Yasunaga, and Feldman, they attribute the low litigation rate to the delays and attorney fee structure. Hagihara, Nishi, \& Nobutomo (2003) examine 435 cases from 1986-1998 in the major

8 A similar suggestion appears in Ramseyer \& Nakazato (1999: 69-70). Foreign exchange rates obviously represent a moving target. Over the past decade, however, $\$ 1.00$ has tended to trade for about 100 yen. The dataset below runs from 1995 to 2004. In January 1995, \$1.00 went for 101 yen. In December 2004, it equalled 103 yen. 
district courts (apparently a database that overlaps with that of Maeda, Sakamoto, \& Nobutomo). They find that 47 percent of the cases involved wrongful-death claims, that 32 percent resulted in a plaintiff recovery, and that the successful claimants in the wrongful-death cases collected a mean of 28 million yen.

Other studies focus more narrowly on specific medical procedures or issues. Hiyama, et al. (2006), examine malpractice claims over endoscopies, for instance, while Shimada \& Kato (1994) survey anesthesia-related claims. Hamasaki, Takehara, \& Hagihara (2008) and Aoki, et al. (2008) both study doctor-patient communications in malpractice disputes.

\subsection{Other Comparisons}

Perhaps because malpractice in most societies outside the United States involves small aggregate transfers, we know less about the claiming processes in other countries. In most advanced democracies, patients file far fewer claims than in the United States. But-importantly given the focus of this paper-in most of these countries the government has also for years more closely controlled the medical services industry.

The United Kingdom and Canada couple a universal health care program with legal systems otherwise similar to that in the United States. Both have little malpractice litigation. In the United Kingdom, the National Health Service estimates its annual expenditures for malpractice at $\$ 642$ million (fiscal 2001-2002, on a population of 59 million; Wheat, 2005). In Canada, on a population of 32 million, plaintiffs filed 1,083 malpractice suits in 2004 (CHSRF, 2006). Trebilcock, Dewees, \& Duff (1990: 542) estimate that "the average frequency of claims filed against physicians in the U.S. is about five times greater than in Canada."

In several other advanced democracies, the government has displaced the tort regime from malpractice entirely. In New Zealand, Sweden, Denmark, and Finland, for instance, it has imposed no-fault instead (OECD, 2006: 13-14).

\section{THE JAPANESE HEALTH CARE INDUSTRY}

\subsection{Universal Health Insurance}

The Japanese government offers universal health insurance, and does so at low cost. Although it purports to cover nearly all citizens for nearly all care, the program costs barely 8 percent of GDP. By contrast, the United States 
spends 15 percent or more of its GDP on health care, and even France and Germany spend 10 and 11 percent (Nihon Iryo, 2007).

The Japanese universal insurance program dates from the late 1950s (Ramseyer, 2009). Facing electoral challenges from a socialist and communist left, the conservative ruling party folded existing health insurance programs into a national insurance plan. Formally, the "plan" was not one but several. It allocated residents to different programs by their age and employment status. Employees in large firms it registered in one set of plans, for example, and those in small firms in another. The employees of the large firms it insured with private insurers, the self-employed with municipal governments (Kameoka, 2005: 8-13).

Through these plans, the Japanese government claims to cover all residents against the cost of most major medical problems. According to political scientist John Campbell and health care specialist Naoki Ikegami (1998: 1-2), "[v]irtually the entire population is included in mandatory health insurance." Through the insurance, the government "covers nearly all regular health care."

\subsection{Service Providers}

The 270,000 physicians (2.0 per 1000 population compared to 2.3 in the United States) who provide the services under the Japanese universal plan fall broadly into two groups: (a) the men and women who run the small, often low-quality clinics, and (b) the doctors who staff the larger hospitals and sometimes offer very high quality care. About a third of all Japanese physicians work in the private clinics. Defined as institutions with fewer than 20 beds, these are small private affairs. The senior doctor either owns the clinic directly or (effectively) owns it through a non-profit organization he controls.

Of all practicing doctors in Japan, 93,000 work in one of these small clinics (Kosei rodo sho, 2006: tab. 2-46). Seventy-one thousand own their own clinic, and another 22,000 work for someone else. Having invested heavily in their clinics, eventually they often transfer them to their sons or daughters. ${ }^{9}$ Depending on the clinic's size, the physician may also hire one or two nurses, and a receptionist. Sometimes, he will employ a pharmacist on staff

9 Given the difficulty their children sometimes have in gaining admission to medical schools, several private schools function-effectively-as schools of last resort for the not-very-bright offspring of very wealthy clinic owners. Teikyo University in Tokyo, for example, demands tuition and fees of 14.2 million yen in the first year. Over the six years of medical school education, it collects tuition and fees of about 49.2 million. 
and sell the drugs he prescribes. He will not have admitting privileges at a larger hospital.

Most of the remaining physicians work as salaried employees at the larger hospitals (Kosei rodo sho, 2006: tab. 2-46). The most sophisticated work at the hospitals associated with elite medical schools. Others practice at the larger hospitals run by national, prefectural, or municipal governments. Still others work at the hospitals operated by charitable organizations like the Red Cross.

\subsection{The Political Economy}

The government sets its prices through negotiations with the physician

trade association. Every other year, representatives of the Ministry of Health, Labor \& Welfare (MHLW) negotiate a fee schedule with the JMA (Campbell \& Ikegami, 1998: ch. 6). The JMA, in turn, advances the interests of the clinic doctors. It may include only 61 percent of all Japanese doctors, but it includes virtually everyone who runs a clinic. ${ }^{10}$

By all accounts, the government sets prices low, but low in a way that favors the clinic doctors over their hospital competitors. According to Campbell \& Ikegami (1998: 147), it sets the prices at about one quarter of the level the service would cost in the United States. Crucially, it also skews the prices in ways that divert revenue away from doctors who invest in specialized expertise. It diverts revenue toward those who invest in the small clinics. ${ }^{11}$

As Campbell \& Ikegami (1998: 84, 173-174) explain it, the government "makes inexpensive primary care relatively profitable and expensive hightech procedures unprofitable." This "[c] ontinued domination by the JMA" of health policy, they (1998: 174) write,

10 Data on total physicians from Kosei rodo sho (2006) for 2004; data on JMA membership from its webside, www.med.or.jp for 2006. See Ramseyer (2009b).

The political economy of the domination of the JMA by the owner-physicians rather than the staff-physicians is reasonably straightforward. First, the owner-doctors own a larger capital investment, and its value hinges on government policy and regulation. Second, because many of the staff-doctors plan eventually to build their own clinic or hospital, they stand at a transitional stage in their career. Notwithstanding this domination by owner-physicians, the JMA continues to work to bring staff-doctors within its ambit. See, e.g., Fukuda (2007: 188); Takeda (2008).

11 To be sure, relative prices are something of a moving target-and the clinic physicians may steadily be losing influence on policy. The basic pricing advantage to simple, low-tech procedures, however, remains. 
[has] left hospital services, especially high-tech medicine and nursing, poorly reimbursed, with no provision for capital investment or administrative overhead.... [O]ffice-based physicians and the government have become de facto allies in maintaining the status quo by preventing the encroachment of hospitals and the expensive high-tech medicine that they promote. the JMA uses its power in ways that extend beyond the price schedule. Through the regulatory structure, it maintains a variety of anti-competitive restraints: ${ }^{13}$ caps on new beds in a locality, advertising restrictions, higher fees for patients who try to consult with a sophisticated hospital without first visiting a small clinic, ${ }^{14}$ and bans on corporate hospital ownership.

Informally, the government often capitulates to local physician opposition to the construction of larger and more sophisticated hospitals. ${ }^{15}$ American physicians lobby for municipal hospitals because they need places to admit their patients. JMA physicians face no such incentive. Instead, they earn the most if they keep their patients out of the hospital and in their own clinic. To them, a community hospital is simply a more sophisticated competitor for their most lucrative customers. Often, they fight plans to build new municipal hospitals in their cities. Often, the government defers.

\subsection{Consequences}

\subsubsection{Not preventive care}

Perhaps the health-care debate in the United States leads readers to think that the skewed pricing structure in Japan might improve primary care. Perhaps it leads them to think that the shift away from technology toward office visits might promote "preventive" medicine.

12 The domination of medical policy by the JMA is famous. See, e.g., Campbell \& Ikegami (1998: 32); see also Ouchi (2005: 129).

13 See Kokuritsu shakai (2006: 428 tab. 229) (bed caps), Iryo ho [Medical Services Act], Law No. 205 of 1948, Sec. 6-5 (advertising restrictions), Yashiro, Suzuki, \& Suzuki (2006: 28) (surcharge on hospital visits), Iryo ho, supra, at Sec. 7(3) (corporate ban).

14 A rule that could—paradoxically—aggravate misdiagnosis claims, since it funnels patients to the least sophisticated practitioners for triage.

15 For examples of the way that local medical associations fight the construction of new hospitals, see the controversy in the Musashimurayama area, detailed at http://www1.neweb.ne.jp/ $\mathrm{wb} / \mathrm{misikai} / \mathrm{sub} 8 . \mathrm{html}$, and the controversy in Kannondera city, detailed at http://www .shikoku-np.co.jp/feature/tuiseki/003/index.htm. The JMA also worked to promote regional limits on hospital beds, as described earlier in the text. See Campbell \& Ikegami (1998: 67). 
At least in Japan, the skewed pricing does neither of these. Because the 43 government sets even primary care prices below market-clearing levels, doctors relentlessly depreciate quality (Ramseyer, 2009a, 2009b). The insurance program pays them per visit, so they keep visits short and see as many patients per day as possible. ${ }^{16}$ It pays them for medication, so they prescribe and sell large amounts of drugs. It reimburses in-patient care at high levels, so they keep patients far longer than in the United States or western Europe. ${ }^{17}$

The insurance does not promote preventive care for a simple reason: it does not cover it. The insurance covers only treatments for accidents and disease, and preventive care falls under neither. Many middle-class Japanese do obtain excellent preventive care, but they pay for it in cash. For the popular batteries of periodic tests called "human docks," they pay 40,000 to 100,000 yen. $^{18}$

\subsubsection{Not health}

Then again, perhaps readers attribute Japanese life expectancies to medical care. Japanese do live long. At birth, white American males can expect to live 75 years (females, 80). Japanese males can expect to live 79 years ( $\mathrm{fe}$ males, 86). Even at age 40, Japanese men have a life expectancy of another 40 years (women, 46) while white American men have only 38 years (women, 42).

Life expectancy depends on many factors, however, of which sophisticated medical care is but one. Of those factors, it is not even the most important. Clean water, sanitation, and treatments for infectious diseases all matter too (Cutler \& Miller, 2004; Cutler, Deaton, \& LlerasMuney, 2006), and on these factors the United States and Japan do not

16 The popular Japanese adage is "to wait 3 hours for a 3 minute consult." Discussed more fully at Ramseyer (2009a).

17 The mean in-patient stay in Japan is 36.3 days. The comparable figures for the United States, United Kingdom, Germany, and France are 6.5, 7.2, 10.4, and 13.4 days. See Ramseyer (2009a).

18 The phrase refers to the process of hooking the patient up to a series of diagnostic machines, much like a ship docked at a harbor. The session provides a long battery of tests for diseases that hit the middle-aged. The tests are not covered by the national insurance. For shorter versions that take one day, the fees run 40,000-60,000 yen; the two-day sessions run 50,000-100,000 yen. See http://www.medicapark.com/knowledge/dock_bean03.html. Some insurance programs may cover these tests. 
markedly differ. Smoking matters as well, and Japanese smoke more than Americans do.

But food and exercise also matter. Japanese eat less saturated fat, and eat less generally. Given urban geography, they walk much farther. As a result, they stand considerably trimmer than most Americans. Among Americans, 34.1 percent are overweight (BMI of 25-30) and 32.2 percent are obese (BMI over 30). Among Japanese, only 20.3 percent are overweight and barely 3.1 percent obese (WHO, 2008). Excess weight takes a large toll. By age 40, an overweight man can expect to live 3 fewer years; an obese man can expect 7 fewer (Peeters, et al., 2003). As Comanor, Frech, \& Miller (2006: 22; see also Frech, 2008) put it, "the relatively poor health outcomes reported for the United States result from a particular risk factor prominent in the U.S.: high obesity rates." The longer lifespan in Japan than in the United States does not reflect better medical care. In part, it merely reflects the choices people make about caloriesin and calories-out.

\subsubsection{Not specialized expertise}

The universal health insurance does ensure that doctors not specialize. Effectively, it eliminates any financial incentive for them to do so. Because the universal coverage boosts demand while the licensing regime cuts supply, Japanese physicians can fill their days at government rates. They will fill their days at government rates if they spend years acquiring specialty and subspecialty skills, and they will also fill their days at government rates if they invest in no specialty training at all.

Predictably, most Japanese doctors choose not to acquire specialized expertise. They do what they must for their basic license, but no more. Of the 19,000 JMA members in Tokyo (56 percent of all Tokyo doctors), barely 1,100 advertise themselves as board-certified. Earning no returns to specialization, those at the clinics treat (virtually) any ailment a patient might bring. Typically, they advertise services in multiple fields. Often, they advertise services in completely unrelated fields like internal medicine and surgery (Ramseyer, 2009a).

\subsubsection{Not sophisticated procedures}

As noted earlier, moreover, the Japanese insurance program also cuts the number of doctors and hospitals that offer the more sophisticated and complex procedures: bypass operations and angioplasty for 
heart disease, for example, carotid angioplasty and endarterectomy to prevent strokes, or the complex operations and chemotherapies for cancer. Potentially, these technologically intensive procedures can save lives. Although a few early studies suggested that some brought only modest returns (McClellan, McNeil \& Newhouse, 1994), more recent work indicates that - when used appropriately - they can generate large benefits. ${ }^{19}$

Japanese doctors perform these complex procedures far less often than their U.S. peers. In 2005, for instance, American doctors performed 469,000 cardiac bypass (coronary artery bypass graft; CABG) operations and 1.27 million angioplasties. Although Japan had about a quarter the number of deaths from heart disease, Japanese doctors performed less than 3 percent of the U.S. bypass operations $(12,000)$, and less than 6 percent of the angioplasties $(70,000-100,000){ }^{20}$

The Japanese government cuts its cancer treatment costs by refusing to license the new chemotherapy drugs. ${ }^{21}$ Pharmaceutical research is expensive. Even as the industry develops ever more effective chemotherapy regimes, it has paid for the research with ever higher prices. When proven effective, the U.S. government has approved these drugs for use. Nominally out of safety concerns, however, the Japanese government has refused to approve many of them for its insurance coverage.

Denied access to the most effective treatment regimes, more and more Japanese cancer patients simply abandon the universal insurance. They cannot formally abandon it, of course. But rather than make do with its limited chemotherapy options, they turn to a growing group of oncologists who offer the new (U.S.-licensed) treatments on a cash basis.

In part to help Japanese plan for their possible off-universal-insurance chemotherapy needs, an increasing number of insurers offer specifically

19 The literature is massive, but a few of the studies include, Cutler (2007); Hemingway, et al. (2001, 2008); Faxon (2008); Normand, et al. (2001); Guadagnoli, et al. (2000). Obviously, they do not always generate benefits. The procedures themselves carry risks, and when not medically indicated the expected benefits do not outweigh those risks.

20 Japan figures: Sezai, Orime, \& Tsukamoto (2007) and Yomiuri (2008) on number of bypass operations; Yomiuri (2008) and Shukan Asahi (2008) on number of angioplasties. U.S. figures: American Heart Association (2008).

21 For a list of the licensed and unlicensed chemotherapy drugs, see www.cancerinfo.tri-kobe .org. 
"cancer insurance." Aflac was said to dominate the market. In 2007, it alone sold 639,000 new cancer insurance policies. At least eight other firms offered the insurance as well. ${ }^{22}$

\section{DATA}

\subsection{The Databases}

To examine malpractice disputes in detail beyond that disclosed by the administrative office of the courts, I examine all judicial decisions published in the course of a decade. More specifically, I code every district court opinion published from 1995 to 2004 that appears in a search for "medical malpractice" in the Hanrei taikei database. ${ }^{23}$ This yields a population of 351 opinions, 348 civil and 3 criminal. With this information, I produce two datasets: a case-level database, and a prefecture-level database.

\subsection{The Variables}

\subsubsection{Case-level database}

56 I code each opinion for the following variables. Summary statistics appear in Table 3.

\section{a. Financial.}

Award Value: the total amount awarded to the plaintiff. Demand Value: the total amount demanded by the plaintiff.

b. Delays.

File-to-Judgment: Number of years from the year of filing to the judgment, provided filed within 3 years of accident.

Accident-to-Judgment: Number of years from the year of accident to the judgment, provided filed within 3 years of accident.

22 Aflac sold 1.4 million new policies (of all types) in 2007. See 2007 Annual Report, Afurakku no genjo, 2008 [The Present State of Aflac, 2008], at 6, available at www.aflac.co.jp. A web search in mid-2008 disclosed at least 8 other firms offering cancer insurance: Mitsui-Sumitomo Marine, Tokyo Marine, Sonpo Japan, Secom sonpo, AIG, AIU. American Home Direct, and Zurich.

23 That is, under "jiko," I search for “iryo kago.” Hanrei taikei is published by the Dai-ichi hoki firm. Eighteen cases that appeared in the search were dropped as not involving malpractice. 
Table 3. Selected Summary Statistics (III)

\begin{tabular}{|c|c|c|c|c|c|}
\hline & $\mathrm{n}$ & Min & Mean & Median & Max \\
\hline \multicolumn{6}{|c|}{ A. Case Level: } \\
\hline \multicolumn{6}{|l|}{ 1. Financial. } \\
\hline Award Value $(/ 1000)$ & 346 & 0 & 31,100 & 14,500 & 205,000 \\
\hline Demand Value (/1000) & 338 & 589 & 74,400 & 59,400 & 546,000 \\
\hline \multicolumn{6}{|l|}{ 2. Delays. } \\
\hline File-to-Judgment & 265 & 0 & 4.20 & 4 & 11 \\
\hline Accident-to-Judgment & 265 & 1 & 5.82 & 5 & 14 \\
\hline \multicolumn{6}{|l|}{ 3. Recovery. } \\
\hline Plaintiff Recovers & 348 & 0 & .744 & 1 & 1 \\
\hline No Causation & 343 & 0 & .201 & 0 & 1 \\
\hline \multicolumn{6}{|l|}{ 4. Patient. } \\
\hline Male & 341 & 0 & .543 & 1 & 1 \\
\hline Death & 348 & 0 & .592 & 1 & 1 \\
\hline Age & 316 & 0 & 36.3 & 38.5 & 88 \\
\hline \multicolumn{6}{|l|}{ 5. Accident. } \\
\hline Misdiagnosis & 348 & 0 & .124 & 0 & 1 \\
\hline Medication Error & 348 & 0 & .152 & 0 & 1 \\
\hline Surgery & 348 & 0 & .463 & 0 & 1 \\
\hline Obstetrics & 348 & 0 & .155 & 0 & 1 \\
\hline Emergency Room & 348 & 0 & .098 & 0 & 1 \\
\hline Cardiac Care & 348 & 0 & .075 & 0 & 1 \\
\hline Cerebrovascular & 348 & 0 & .103 & 0 & 1 \\
\hline Cancer & 348 & 0 & .167 & 0 & 1 \\
\hline \multicolumn{6}{|l|}{ 6. Institution. } \\
\hline University Hospital & 343 & 0 & .175 & 0 & 1 \\
\hline Government Hospital & 343 & 0 & .207 & 0 & 1 \\
\hline Red Cross Hospital & 343 & 0 & .047 & 0 & 1 \\
\hline Other Public Hospital & 343 & 0 & .125 & 0 & 1 \\
\hline Private Hospital & 343 & 0 & .227 & 0 & 1 \\
\hline Dental Clinic & 343 & 0 & .015 & 0 & 1 \\
\hline Clinic & 343 & 0 & .187 & 0 & 1 \\
\hline
\end{tabular}


Table 3. (Continued)

\begin{tabular}{|c|c|c|c|c|c|}
\hline \multicolumn{6}{|c|}{ B. Prefecture Level: } \\
\hline \multicolumn{6}{|l|}{ 1. Explanatory variables. } \\
\hline Suits & 46 & 0 & 7.57 & 2.5 & 106 \\
\hline Population (/1000) & 46 & 607 & 2,748 & 1,798 & 12,600 \\
\hline$\%$ Population over 64 & 46 & 16.4 & 22.5 & 21.9 & 27.1 \\
\hline$\%$ Agricultural Econ & 46 & .3 & 25.3 & 27.7 & 89.2 \\
\hline Density & 46 & 67.4 & 649 & 268 & 5751 \\
\hline GDP PC (/million) & 46 & 2.7 & 3.5 & 3.6 & 6.5 \\
\hline Hospital Beds & 46 & 9,396 & 34,933 & 24,367 & 129,939 \\
\hline Clinic Beds & 46 & 622 & 3,436 & 2,898 & 10,990 \\
\hline Medical School & 46 & 1 & 1.72 & 1 & 13 \\
\hline Cardiac Bypass & 46 & 0 & 3.74 & 2 & 20 \\
\hline Attorneys & 46 & 28 & 456 & 91.5 & 10,263 \\
\hline \multicolumn{6}{|l|}{ 2. Instruments. } \\
\hline Museums & 46 & 3.3 & 11.2 & 9.85 & 32.9 \\
\hline Concerts & 46 & 9.85 & 12.7 & 12.4 & 15.6 \\
\hline School Internet & 46 & 37 & 70.4 & 71.6 & 92.1 \\
\hline College Grads & 46 & 7.2 & 12.3 & 11.4 & 24.2 \\
\hline
\end{tabular}

Notes: Case data are from published opinion database, as described in text.

c. Recovery.

Plaintiff Recovers: 1 if the plaintiff recovered at least some amount in damages; 0 otherwise.

No Causation: 1 if the court found that the defendant did not fully cause the accident, that the defendant did not fully cause the patient's damages, or that the patient was partially negligent as well; 0 otherwise.

\section{d. Patient.}

Male: 1 if the patient is male; 0 otherwise.

Death: 1 if the patient died from the accident; 0 otherwise.

Age: the age of the patient at the time of the accident.

e. Accident.

Misdiagnosis: 1 if the wrongful act involved a misdiagnosis; 0 otherwise. 
Medication Error: 1 if the wrongful act involved a medication error; 0 otherwise.

Surgery: 1 if the wrongful act involved surgery; 0 otherwise.

Obstetrics: 1 if the wrongful act involved obstetrics; 0 otherwise.

Emergency Room: 1 if the wrongful act took place in an emergency room; 0 otherwise.

Cardiac Care: 1 if the wrongful act involved cardiac care; 0 otherwise. Cerebrovascular: 1 if the wrongful act involved cerebrovascular disease; 0 otherwise.

Cancer: 1 if the wrongful act involved cancer; 0 otherwise.

\section{f. Institution.}

University Hospital: 1 if the wrongful act took place at a university hospital; 0 otherwise.

Government Hospital: 1 if the wrongful act took place at a government (but not university) hospital; 0 otherwise.

Red Cross Hospital: 1 if the wrongful act took place at a Red Cross hospital; 0 otherwise.

Other Public Hospital: 1 if the wrongful act took place at any other public hospital; 0 otherwise.

Private Hospital: 1 if the wrongful act took place at a private hospital; 0 otherwise.

Dental Clinic: 1 if the wrongful act took place at a dental clinic; 0 otherwise.

Clinic: 1 if the wrongful act took place at a clinic; 0 otherwise.

\section{g. Other.}

Year suit filed, year of accident, and geographical dummies for the most often used district courts.

\subsubsection{Prefecture-level database}

At the prefecture-level, I calculate the following variables:

Suits: Number of malpractice suits filed in the prefecture, 1995-2004. Population: Population, 2005.

\% Population over 64: Percentage of population age 65 or older. $\%$ Agricultural Econ: Value of agricultural output, divided by prefectural GDP. 
Density: Population per square kilometer.

GDP PC: Prefectural GDP per capita, in billion yen.

Hospital Beds: Number of hospital beds (MHWL, 2008).

Clinic Beds: Number of clinic beds (MHWL, 2008).

Medical School: Number of medical schools.

Cardiac Bypass: Number of hospitals performing more than 100 heart surgeries (including cardiac by-pass operations but not catheterization) in 2007 (Asahi shinbun shuppan, 2009).

Attorneys: Total number of attorneys, 2004 (Nihon bengoshi rengo kai, 2005).

\subsubsection{Instruments}

As instruments for the number of attorneys per prefecture (see Section 6.1.2(b)), I add:

Museums: Total museums in prefecture (including zoos, aquariums, etc.), 2002 (Toba, 2005).

Concerts: Percent of population (10 years old or older) who attend music concerts (for reasons not explained, the source excludes classical concerts), 2001 (Toba, 2005).

School Internet: Percent of public schools with high-speed internet access, 2003 (Toba, 2005).

College Grads: Percent of population who graduated from a university, 2000 (Toba, 2005).

\subsection{Biases}

\subsubsection{Introduction}

Like Lexis and Westlaw, the Hanrei taikei purports to include all published opinions. Some of these opinions appeared in one or more official (often subject-specific) court reporters. The rest appeared in the private reporters.

My database is biased. Whether a collection of all published malpractice opinions might be biased is not the question: clearly, it is. Publication introduces one obvious bias. The courts decide which opinions to publish officially. Presumably they publish those opinions that they think provide (among other things) proper precedential direction. By contrast (and not to put too fine a spin on it), the publishers of the private reporters are in 
the business of selling magazines. They include those opinions that they think will boost subscription rates.

The very fact of litigation introduces a second bias. We have known at least since Priest \& Klein (1984) that litigated cases—whether published or not-are not a random sample of all disputes. Instead, they represent those disputes that the parties chose not to settle out-of-court. Given that the vast majority of disputes settle, those that do not will potentially differ along several important dimensions.

Consider, then, some evidence about the direction and magnitude of the biases involved.

\subsubsection{The published malpractice opinions represent a larger fraction of the underlying court cases than other published civil opinions}

From 1998 to 2004, the Japanese courts issued 2,298 civil judgments in medical malpractice cases (summing Table 1 Panel A Column (3)). During the same period, the various reporters published 229 (10.0 percent; summing Column (4)). ${ }^{24}$

By contrast, in 2004 court reporters published only 1.9 percent (1358) of all civil judgments. If I exclude default judgments, they published 3.0 percent (from Hanrei taikei database; Shiho tokei, 2004: tab. 20). Apparently, reporters publish about five times as many malpractice opinions as civil opinions more generally. A large fraction of the civil suits represent legally mundane traffic accidents and debt-collection disputes. As a relatively new field, medical malpractice opinions raise more interesting issues, and the reporters publish a bigger fraction of them.

\subsubsection{The plaintiffs in the published malpractice cases win more often than malpractice plaintiffs generally}

According to Panel B of Table 1, the fraction of cases that the publishedopinion plaintiffs won rose from 65-75 percent in 1995-2001 to over 90 percent by 2003. During the same period, plaintiffs in malpractice cases as a whole. published and unpublished, won only 30 to 45 percent. Recall from Section 1.1, above, that plaintiffs in U.S. malpractice cases win about 20-30 percent.

24 In 2002, Texas claimants filed 6,929 “claims" (Black, et al., 2005: 246 tab. 13). A simple Lexis search for "medical malpractice" for Texas state courts in 2002 yields 109 opinions. 
66

67

Hypothetically, the high plaintiff win-rate in the published cases might reflect a desire among judges to encourage malpractice claims. In fact, it does not. The official reporters nearly boycotted the malpractice field. During the ten years involved, they published only fifteen opinions in civil malpractice opinions. Among them, the plaintiffs won only eight.

The high plaintiff win-rates instead track the editorial bias at the commercial reporters. Perhaps the editors liked malpractice opinions, but thought plaintiff losses bored their readers. Apparently, they decided that plaintiff victories offered subscribers a "better read" than plaintiff losses. Among the 337 cases in the private reporters, plaintiffs won 75.4 percent.

\subsubsection{Wrongful-death claims constitute a slightly higher percentage of the published malpractice cases than the unpublished}

68 Among the published cases, 59.5 percent involved patients who died (Table 4). For all malpractice cases, the administrative office does not release the comparable fraction. Nonetheless, Hagihara, Nishi, \& Nobutomo (2003) study all malpractice decisions (435) in ten district courts over 1986-1998. Examining both published and unpublished decisions, they find that 47.0 percent involved deaths. Apparently, the published opinions involve disproportionately many death claims. ${ }^{25}$

\subsubsection{Plaintiffs disproportionately sue in Tokyo and Osaka, as the published-opinion database reflects}

The administrative office of the courts does not disclose where malpractice plaintiffs bring their claims. In what seems the same procedure as Hagihara, Nishi, \& Nobutomo (2003), however, Maeda, Sakamoto, \& Nobutomo (2001) survey all (published and unpublished) malpractice cases from 1989-1998 for ten district courts (excluding Yokohama). They do disclose the number of cases from each court, and I report the numbers in Table 1 Panel C Column (3).

Disproportionately, malpractice claimants sue in Tokyo and Osaka. According to the Maeda, Sakamoto, \& Nobutomo database, they filed 41 percent of all malpractice cases in Tokyo and 27 percent in Osaka. Among civil cases more generally, plaintiffs filed only 21 percent in Tokyo and 9 percent in Osaka (Column (2)).

25 Alternatively, of course, the difference could reflect the differing time periods at stake. 
Table 4. Amounts Recovered

\begin{tabular}{|l|c|c|c|c|c|}
\hline \multirow{2}{*}{} & (1) & (2) & (3) & (4) & (5) \\
\cline { 2 - 6 } & Total Payout & $\begin{array}{c}\text { Percent } \\
\text { Death }\end{array}$ & \multicolumn{3}{|c|}{ Mean Payout } \\
\cline { 2 - 6 } & & & Pub. & Death (Pub.) & All. \\
\hline 1995 & $979^{\star}$ & $69.0 \%$ & $23.3^{\star}$ & $38.9^{\star}$ & $24.0^{\star}$ \\
\hline 1996 & 834 & 68.2 & 19.4 & 51.4 & 15.3 \\
\hline 1997 & 564 & 72.7 & 17.1 & 36.5 & 15.4 \\
\hline 1998 & 1,041 & 57.9 & 27.4 & 55.8 & 40.1 \\
\hline 1999 & 957 & 69.6 & 41.6 & 61.9 & \\
\hline 2000 & 1,181 & 47.9 & 25.3 & 53.6 & \\
\hline 2001 & 1,408 & 52.3 & 32.0 & 63.0 & \\
\hline 2002 & 1,338 & 50.0 & 44.6 & 38.3 & \\
\hline 2003 & 1,485 & 46.7 & 49.5 & 49.7 & \\
\hline 2004 & 954 & 62.5 & 59.6 & 74.7 & \\
\hline $1995-2004$ & 10,761 & 59.5 & 31.1 & 50.0 & \\
\hline
\end{tabular}

Notes: *Payout numbers are in million yen. Column (3) includes cases in which plaintiff did not recover. Column (4) is limited to wrongful death cases in which the plaintiff recovers at least some amount, and where the court does not reduce recovery for contributory negligence or causation issues.

Columns (1)-(4) are from the published opinion dataset, as described in the text. Column (5) is from Maeda, Sakamoto, \& Nobutomo (2001), and gives the mean pay out in all cases filed in court, including those that settle.

If anything, published malpractice opinions disproportionately include cases not from Tokyo or Osaka. Only 31 percent of the published cases come from Tokyo and 16 percent from Osaka (Column (1)). Recall, however, that Maeda, Sakamoto, \& Nobutomo only survey 10 district courts. Tokyo and Osaka cases are a larger fraction of their universe- but their universe includes fewer than all courts.

For the most part, any geographical bias may not matter. Other than on time-to-judgment (see Subsection 3.3.6, below), the courts seem not to differ on any dimension measured here. ${ }^{26}$ Indeed, Hagihara, Nishi, \& Nobutomo (2003: 121) assert that "there are no reports on regional differences in medical malpractice decision-making" among the different courts.

26 As explained below (Sec. 4.4.3.), however, Japanese courts do hold doctors to a standard of care that varies in part by the local environment. 
Table 5. Geographical Differences

\begin{tabular}{|l|c|c|c|}
\hline & $\mathbf{( 1 )}$ & $\mathbf{( 2 )}$ & $\mathbf{( 3 )}$ \\
\hline Dependent variable & Plaintiff Recovers & Award Value & File-to-Judgment \\
\hline Tokyo & $.025(0.13)$ & $-5.95(0.94)$ & $-.811(2.56)^{\star \star}$ \\
\hline Osaka & $.479(1.86)^{\star}$ & $-9.55(1.35)$ & $-.110(0.31)$ \\
\hline Nagoya & $.208(0.54)$ & $-12.1(1.10)$ & $1.340(2.54)^{\star \star}$ \\
\hline Yokohama & $-.078(0.20)$ & $3.96(0.31)$ & $-.650(1.18)$ \\
\hline Kobe & $.288(0.62)$ & $-.24(0.02)$ & $-.060(0.09)$ \\
\hline Fukuoka & Dropped & $-3.59(0.33)$ & $-.267(0.42)$ \\
\hline Shizuoka & $-.736(1.49)$ & $-5.98(0.26)$ & $2.281(2.35)^{\star \star}$ \\
\hline Male & $.089(0.53)$ & $14.6(2.91)^{\star \star \star}$ & $.179(0.70)$ \\
\hline Age & $.021(1.84)^{\star}$ & $.15(0.41)$ & $-.013(0.76)$ \\
\hline Age Sq & $-.003(1.97)^{\star}$ & $-.007(1.45)$ & $-.000(0.04)$ \\
\hline Death & $-.167(0.96)$ & $-6.09(1.20)$ & $.432(1.62)$ \\
\hline No Causation & & $-30.1(5.25)^{\star \star \star}$ & $.574(1.81)$ \\
\hline Pltf Recovers & & & $-.049(0.16)$ \\
\hline Demand Value & & & $5.58 @(2.42)^{\star \star}$ \\
\hline $\mathrm{n}$ & 299 & 241 & 239 \\
\hline Adj/pseudo $\mathrm{R}^{2}$ & .04 & .18 & .12 \\
\hline Regression & Probit & OLS & \\
\hline
\end{tabular}

Notes: $* \star \star, ~ * \star, ~ *$ : significant at 1\%, 5\%, and 10\% levels. @ is $\times 10^{9}$. Coefficients in Column (2) are divided by $10^{6}$, and dataset in is limited to Pltf Recovers $=1$. Published opinion dataset, as described in text.

The published-opinion dataset seems largely to confirm the Hagihara, Nishi, \& Nobutomo claim (Table 5). Whether on the likelihood of recovery or the amount of damages received, the differences among the various courts are largely insignificant.

\subsubsection{The published malpractice cases take longer to adjudicate than the unpublished malpractice cases}

The plaintiffs in the published cases litigate longer than those in the unpublished cases. According to Table 1 Panel B, from 1998 to 2004, filing-to-judgment times for malpractice cases as a whole fell from about three years to two. During the same period, the filing-to-judgment times among the published cases fell, but remained higher: from about 4.5 years to 3.5. 
The longer times-to-judgment in the published opinion database may 75 reflect in part the slightly smaller fraction of Tokyo and Osaka cases (see Subsection 3.3.5, above). For reasons discussed elsewhere (Ramseyer, 2010), Tokyo and Osaka courts handle malpractice cases quickly. The phenomenon appears in Table 5 Column (3), where I regress time-tojudgment on the geographical variables. Parties that litigate their malpractice case in Tokyo can expect a decision nearly a year earlier than those who litigate it in one of the courts not listed.

The longer filing-to-judgment times among the published cases probably also reflect the higher stakes involved. In my Table 5 regression, I regress time-to-judgment on (inter alia) the amount the plaintiff demanded. The resulting coefficient is both positive and statistically significant.

\subsubsection{The published malpractice cases involve medical procedures similar to those among malpractice cases generally}

Though not comprehensively, the administrative office does disclose some information about the types of medical procedures that generate the malpractice suits. Of the 2005 suits, for example, 39 percent involved surgery. Fourteen percent involved obstetrics or gynecology (see Table 2 Panel A).

The plaintiffs in the published opinions sued on a similar mix of suits. Of these opinions, the plaintiffs in 46 percent sued on surgical procedures. Fifteen percent sued on obstetrical or gynecological procedures.

\subsubsection{Addendum: Comparison to settled cases}

a. Yoshikawa. In 2006, prominent malpractice plaintiff's attorney Kozaburo Yoshikawa published a book detailing 45 malpractice cases he had settled (Yoshikawa \& Makabe, 2006). Over the course of his career (1978-2005), he explained, he had fielded about 510 inquiries from clients or potential clients. Of those, he had pursued about 100 . The rest he had concluded showed too low a probability of success. Of those $100+$ cases, he then detailed the major cases that resulted in a plaintiff recovery: 45 cases that settled, and 12 cases that went to a court decision.

Given the obvious incentive facing Yoshikawa to exaggerate his career success, these cases are decidedly non-random. That said, he reports:

- Of the 45 cases settled, 26 (58 percent) involved death claims (published opinion database: 59 percent). 
- Fifty-three percent of the claimants were male, with a mean age of 42 (published opinion database: 54 percent male, with a mean age of 36).

- The plaintiffs in the wrongful-death cases received settlements that ranged from 2 million yen to 80 million, with a mean of 29.7 million yen and a median of 30 million. Of the six cases with sub-10-million-yen recoveries, three were cancer cases (hence plaintiffs with a low life expectancy) and two involved patients over age 70 (published opinion database: recoveries of 200,000 yen to 189 million, with a mean of 40.6 million yen and a median of 37.5). ${ }^{27}$

- The nineteen claimants with non-death claims received settlements that ranged from 5 million yen to 70 million, with a mean of 40 million and median of 50 million (published opinion database: 200,000 yen to 205 million, with a mean of 43.6 million and a median of 20.7 million).

b. Tokyo District Court. Other evidence does indeed suggest that Yoshikawa's settled cases probably include unrepresentatively generous settlements. The Tokyo District Court examined all cases in its malpractice panel that settled during April 2001 to September 2002 (Tokyo chiho saibansho iryo sosho taisaku iinkai, 2003: 35-36, 45). In Table 6, I compare these settlements with the comparable statistics for the published opinion database.

Note two facts about these settlements. First, the plaintiffs settled for a smaller fraction of the amounts they demanded than the litigating plaintiffs eventually obtained. Of the settling plaintiffs, 36 percent obtained at least half of their demand. Of the published opinion plaintiffs, over 51 percent did. This is of course exactly what one would expect if parties settled for amounts that reflected a discount for their likelihood of recovery.

Second, the settling plaintiffs obtain relatively small amounts. Only 27 percent of the settling plaintiffs recovered 20 million yen. Of the published opinion database, a full 58 percent did. This too is what one would expect if settling plaintiffs discounted their expected recovery by the likelihood of success - and is consistent with the general phenomenon of smaller-stake disputes settling more readily than larger-stake disputes.

27 Given the high cancer mortality rates, Yoshikawa \& Makabe (2006: 113) noted that recoveries were low in cancer cases. 
Table 6. Settlement and Litigation, by Award/Demand

\begin{tabular}{|l|c|c|}
\hline Award/Demand & $\begin{array}{c}\text { Settled } \\
\mathbf{n}(\%)\end{array}$ & $\begin{array}{c}\text { Litigated } \\
\mathbf{n}(\%)\end{array}$ \\
\hline less than $20 \%$ & $11(24.4 \%)$ & $57(21.7 \%)$ \\
\hline $20 \leq \times<30 \%$ & $4(8.9)$ & $21(8.0)$ \\
\hline $30 \leq \times<40 \%$ & $9(20)$ & $25(9.5)$ \\
\hline $40 \leq \times<50 \%$ & $5(11.1)$ & $25(9.5)$ \\
\hline $50 \%$ and over & $16(35.6)$ & $135(51.3)$ \\
\hline Total & 45 & 263 \\
\hline Over 20 million award: & $12(26.7 \%)$ & $153(58.2 \%)$ \\
\hline
\end{tabular}

Note: The table gives the number (and percentage) of cases that fell in a given range of the amount of the award divided by the amount demanded by the plaintiff. The settled cases are all Tokyo District Court cases settled between April 2001 and September 2002, as investigated by the committee of the Tokyo District Court (as described in the text). The litigated cases are those in the published-opinion database (as described in the text) that resulted in some recovery to the plaintiff.

\section{LITIGATION}

\subsection{Introduction}

With this data, I explore several related questions: (1) Whom do Japanese plaintiffs sue (Section 4.2)? (2) How much do they collect (Section 4.3)? (3) Why do the patients sue the doctors that they do (Section 4.4)? (4) Overall, how much claiming occurs (Section 5)? And (5) why are claiming levels as low as they are (Section 6)?

\subsection{Whom Do Patients Sue?}

\subsubsection{University professors, not private doctors}

Disproportionately, Japanese patients sue their university professors rather than their clinic doctors. ${ }^{28}$ University hospitals contain 6 percent of all beds; their physicians defend 18 percent of all malpractice suits. The

28 Note that I cannot rule out the possibility that the clinics and hospitals use different settlement practices. These data are consistent with a world where clinic doctors settle most of the claims against them, while the universities refuse to settle and litigate instead.

As I explain much more fully in Section 4.4 below, it is perfectly logical that university hospitals would be the primary target: they use large teams, take the sickest patients, use the most sophisticated technology, and perform the most complicated procedures.

Note that the litigation and settlement of the claims against the clinic doctors would be controlled by the casualty insurance firm underwriting the medical association's liability policy; the litigation and settlement of the claims against the (self-insured) university hospital would be controlled by the senior officers of the university. 
small private clinics and hospitals supply 55 percent of all beds; their doctors defend barely 41 percent of the suits (Table 2, Panel B). Were plaintiffs suing over low-quality care, they would sue the doctors running the clinicmills. Instead, they sue the sophisticated specialists at the university hospitals. Given that most clinic doctors buy the standard JMA malpractice insurance, the plaintiffs are not suing the hospitals for the deep pocket. Covered up to 100 million yen, the clinic doctors have pockets as deep as the plaintiffs need.

In suing the university doctors, Japanese patients are not suing their worst doctors. They are suing their best-albeit high-quality doctors who may have made negligent mistakes. After all, as in the United States, the physicians at the university hospitals represent the very brightest doctors, the top of the medical quality distribution.

The doctors who staff the university hospitals attended the most competitive universities. They performed at levels that earned them a position on a university hospital staff. Despite the lack of financial incentives, they trained for years in their specialty, and often in a subspecialty (sometimes at U.S. hospitals). And the best of them provide care as sophisticated as anything available anywhere in the world.

At the other extreme are the clinic doctors. Because of the national health insurance payment schedule, a third of the doctors in Japan choose to operate these rudimentary private clinics. They keep a few beds, and hire a nurse and perhaps a pharmacist. They then run as many patients through the clinic as they can. Paid by the visit, they make them return time and again. They keep them hospitalized for long periods. They sell them large quantities of drugs.

These clinic doctors do not specialize. Instead, they hold themselves out as both internists and surgeons, and treat whoever walks in the door. Many of them inherited their clinics from their parents, and attended bottomtiered medical schools. Primarily because of the large tuition difference (and with a few notable exceptions), most of the medical schools associated with the public universities are more selective than most of the private medical schools. ${ }^{29}$ Yet while private schools graduate 39.5 percent of the physicians each year, they educate most of the Tokyo clinic owners. ${ }^{30}$

29 See, e.g., http://daigaku.jyuken-goukaku.com/nyuushi-hensati-ranking/igakubu.

30 Take the Tokyo JMA members at the most active phase of their career-those born between 1955 and 1967. Of those operating private clinics, 72.5 percent attended a private school. Database prepared for Ramseyer (2009a). 
Table 7. Determinants of Malpractice Litigation

\begin{tabular}{|c|c|c|c|c|c|c|}
\hline & (1) & (2) & (3) & (4) & (5) & (6) \\
\hline \multicolumn{7}{|c|}{ Dependent variable: Suits } \\
\hline Population & $\begin{array}{l}22.2 \\
(1.14)\end{array}$ & $\begin{array}{c}-3.68 \\
(0.36)\end{array}$ & $\begin{array}{r}-4.37 \\
(0.41)\end{array}$ & $\begin{array}{c}-5.59 \\
(0.57)\end{array}$ & $\begin{array}{r}-10.6 \\
(0.53)\end{array}$ & $\begin{array}{r}-22.4^{\star \star} \\
(2.28)\end{array}$ \\
\hline Hospital beds & $\begin{array}{l}.040^{\star} \\
(1.87)\end{array}$ & $\begin{array}{l}.043^{\star \star \star} \\
(3.89)\end{array}$ & $\begin{array}{r}.017 \\
(1.46)\end{array}$ & $\begin{array}{l}.030^{\star \star} \\
(2.67)\end{array}$ & $\begin{array}{l}.028 \\
(1.43)\end{array}$ & $\begin{array}{l}.035^{\star \star \star} \\
(3.70)\end{array}$ \\
\hline Clinic beds & $\begin{array}{l}-.199^{\star} \\
(1.88)\end{array}$ & $\begin{array}{l}-.182^{\star \star \star} \\
(3.31)\end{array}$ & $\begin{array}{l}-.140^{\star \star} \\
(2.46)\end{array}$ & $\begin{array}{l}-.161^{\star \star \star} \\
(3.08)\end{array}$ & $\begin{array}{l}-.200^{\star \star} \\
(2.10)\end{array}$ & $\begin{array}{l}-.184 \\
(3.95)^{\star \star \star}\end{array}$ \\
\hline Medical school & & & $\begin{array}{l}7.585^{\star \star \star} \\
(10.29)\end{array}$ & $\begin{array}{l}3.671^{\star \star} \\
(2.56)\end{array}$ & & \\
\hline Cardiac bypass & & & & & $\begin{array}{l}3.004^{\star \star \star} \\
(3.32)\end{array}$ & $\begin{array}{l}1.881^{\star \star \star} \\
(4.17)\end{array}$ \\
\hline n: & 46 & 45 & 46 & 45 & 46 & 45 \\
\hline Adj. $R^{2}$ & .66 & .67 & .90 & .71 & .73 & .77 \\
\hline Regression: & OLS & OLS & OLS & OLS & OLS & OLS \\
\hline Prefectures: & All & Ex Tokyo & All & Ex Tokyo & All & Ex Tokyo \\
\hline
\end{tabular}

Notes: ${ }^{* \star *},{ }^{* *}, *$ : statistically significant at the 1,5 , and $10 \%$ levels.

Coefficients, followed by the absolute value of the $t$-statistic on the line below. Population coefficients are $\times 10^{7}$; bed coefficients are $\times 10^{2}$. All regressions include a constant term. All prefectures except Okinawa.

\subsubsection{Hospitals, not clinics}

To explore further the identity of the doctors whom patients sue, in Table $7 \quad 90$ I regress the number of malpractice cases in a prefecture (published opinions, 1995-2004) on several sets of prefecture-level independent variables. ${ }^{31}$ In Column (1), I regress the number of suits on the number of hospital beds and clinic beds. The message is simple: in a race between the number of hospital beds and clinic beds, hospital beds win. The median prefecture has about 24,000 hospital beds. A 10 percent increase would raise the number of malpractice suits by about $1-$ a substantial increase over the prefectural median of 2.5. The median prefecture has 2,900 clinic beds. A 10 percent increase would decrease the number of suits by about

31 Elsewhere, I add the number of attorneys to the regression. I omit Okinawa in these estimates because of lingering differences in the structure of the legal services industry caused by the long American occupation of the islands. 
0.6. Sophisticated care generates more malpractice claims, simple care generates fewer: the greater the number of hospital beds in the prefecture, the greater the number of malpractice suits; the greater the number of clinic beds, the smaller the number of malpractice suits. ${ }^{32}$

\subsubsection{Complex medicine, not simple}

91 Similarly, in a horse race between complex care and simple, complexity wins. In Column (3) of Table 7, I regress the number of suits on the number of medical schools in the prefecture. Because the university hospitals specialize in the highest-risk patients, the most difficult diseases, and the most complex, technology-intensive medical procedures, the number of university hospitals proxies for the level of medical sophistication generally. Again, the message is simple: the more medical schools in a prefecture (the higher the level of medical sophistication), the more malpractice suits. The coefficient of 7.58 is enormous, but not implausibly so. Thirty-four prefectures have 1 medical school (no prefectures have none); they have a median of 1 malpractice suit. The other 12 prefectures have a median of 11.5 suits. The coefficient on the number of clinic beds remains significantly negative.

In Column (5), I regress the number of suits on the number of hospitals in a prefecture doing more than 100 CABG operations. CABG operations do not themselves generate more than a few malpractice claims. Because of their difficulty, however, they proxy for the level of medical sophistication in a community. The CABG operation is extraordinarily difficult, and prefectures that do more of them will also do more sophisticated medicine generally. Once again, the result is simple: the greater the number of hospitals doing a substantial number of CABG operations (the higher the level of medical sophistication), the greater the number of malpractice suits. The coefficient of 3.00 is large, but plausible. The median prefecture has two such hospitals. The 26 prefectures with two or fewer bypass hospitals have a median of 1 malpractice suit. The other 20 prefectures have a median of 8 suits. Again, the coefficient on the number of clinic beds remains significantly negative.

Because plaintiffs file 30 percent of all malpractice suits in Tokyo, Tokyo could, hypothetically, drive these results. It does not. In Columns (2), (4)

32 The result is not entirely robust. If I both add the number of attorneys as an independent variable and exclude Tokyo, the coefficients on the two bed variables become insignificant. See, e.g., Column (2), Table 10. 
and (6), I run the same regressions without Tokyo. The results remain largely unchanged.

\subsection{What Do They Collect?}

\subsection{1. $\$ 400,000$ lives}

Among the plaintiffs in the published-opinion database, 74 percent recover some amount. As noted earlier, the same is not true of most malpractice plaintiffs. In 2004, plaintiffs filed 1,110 suits. They pursued 405 to judgment, and in those 405 only 40 percent of the plaintiffs recovered anything (Table 1).

Among the published-opinion plaintiffs who collected some amount, recoveries ranged from 200,000 to 205 million yen, with a mean of 41.8 million and a median of 32.9 million —at the approximate exchange rate of 100 yen per dollar, a mean of $\$ 420,000$ and a median of $\$ 330,000$. In wrongful death cases, the awards ranged from 200,000 to 189 million yen, with a mean of 40.6 million and a median of 37.5 million. As in the United States, wrongful-death claims do not generate the highest recoveries. Instead, the long-term disability claims do.

Table 8 Panel A gives the ten highest awards. Seven of the ten involve disability claims, and three involve wrongful death. The highest award was 205 million yen (\$2.1 million), and the highest wrongful-death award was 189 million ( $\$ 1.9$ million).

\subsubsection{Predictably valued lives}

In Table 5, I take those published opinions in wrongful-death cases that yielded a plaintiff recovery and regress the award on the geographical variables, the plaintiff's sex, age, age-squared, whether the plaintiff died, and whether the doctor caused the entire loss. The results indicate that male losses average 15.4 million yen more than female losses. The Age and Age Squared coefficients suggest that the value of life rises initially, and then declines (compare Table 9 Panel B Column (3)).

According to the opinions themselves, the judges calculate wrongful-death awards by present-valuing a decedent's expected earnings. They then subtract about half for forgone maintenance, and add a standard amount for pain and suffering. As Leflar (2009a: 445) and Feldman (2009: 265-66) rightly explain, this is the formula judges developed to standardize damages in automobile accident cases.

The opinions confirm the judges' descriptions of what they do. Largely, they value a life by present-valuing the decedent's lost earnings-hence the 
Table 8. Valuation of Human Life

\begin{tabular}{|l|l|l|l|c|c|c|}
\hline \multicolumn{7}{|c|}{ A. High Awards } \\
\hline Date & Court & Award & Sex & Age & Death & Diability \\
\hline Mar. 13, 2002 & Tokyo & 205 million & Male & 50 & No & Yes \\
\hline Feb. 16, 2004 & Chiba & 189 million & Male & 14 & Yes & No \\
\hline May 26, 2003 & Tokyo & 169 million & Female & 20 & No & Yes \\
\hline Apr. 24, 1998 & Osaka & 153 million & Male & 63 & Yes & No \\
\hline Nov. 21, 2002 & Tokyo & 153 million & Male & 30 & No & Yes \\
\hline Jan. 21, 2004 & Osaka & 150 million & Male & 32 & No & Yes \\
\hline July 29, 1999 & Fukuoka & 145 million & Female & 0 & No & Yes \\
\hline Apr. 19 2001 & Tokyo & 141 million & Male & 4 & No & Yes \\
\hline July 8, 1996 & Kobe & 138 million & Male & 62 & Yes & No \\
\hline Mar. 31, 2003 & Yamaguchi & 137 million & Male & 29 & No & Yes \\
\hline
\end{tabular}

\begin{tabular}{|c|c|c|c|c|}
\hline \multicolumn{5}{|c|}{ B. Human Life Valuation } \\
\hline \multirow{4}{*}{ Age } & (1) & (2) & (3) & (4) \\
\hline & \multicolumn{4}{|c|}{ Estimated using. } \\
\hline & \multicolumn{2}{|c|}{ Traffic Accid. Formula } & \multicolumn{2}{|c|}{ Observed Court Formula } \\
\hline & Men & Women & Men & Women \\
\hline 20 & 72,007 & 52,649 & 50,505 & 47,448 \\
\hline 30 & 72,537 & 45,887 & 64,768 & 51,650 \\
\hline 40 & 68,917 & 39,799 & 71,820 & 47,073 \\
\hline 50 & 61,148 & 34,388 & 65,252 & 42,223 \\
\hline 60 & 49,230 & 29,651 & 44,647 & 35,689 \\
\hline
\end{tabular}

Notes: In 1000 yen. The "Traffic Accident Formula" is the value of human life calculated using the standard formula, with 2.5 million yen for pain and suffering, 1.5 million for funeral expenses, a living expense offset of 50 percent, the sex-specific average Japanese annual earnings given at www.english-resume.net/indiv/ent41-02.php, and standard Japanese Leibnitz discounting tables. The "Observed Court Formula" is the predicted amount using the coefficients calculated through an OLS regression of court awards on Age, Age Squared, and a constant, as discussed in the text.

\begin{tabular}{|c|c|}
\hline \multicolumn{2}{|c|}{ C. Court-Award/Plaintiff-Demand } \\
\hline Award Demand & Fraction of All Cases \\
\hline $0-20 \%$ & $4.6 \%$ \\
\hline $21-40$ & 14.8 \\
\hline $41-60$ & 25.0 \\
\hline
\end{tabular}


Table 8. (Continued)

\begin{tabular}{|c|c|}
\hline \multicolumn{2}{|c|}{ C. Court-Award/Plaintiff-Demand } \\
\hline Award Demand & Fraction of All Cases \\
\hline $61-80$ & 26.9 \\
\hline $81-100$ & 28.7 \\
\hline
\end{tabular}

Mean Award/Demand $=63.5 \%$

Notes: Civil cases only; wrongful death cases only. Excludes those in which the plaintiff did not recover, or where court found comparative negligence or intervening causes.

Sources: Published opinion data base, as described in the text.

differences by sex and age. In Columns (1) and (2) of Table 8 Panel B, I use sex-specific average earnings figures to calculate the value of life for men and women according to the ostensible judicial formula. The numbers peak at about age 30 for men at 73 million yen, and at age 20 for women at 53 million yen.

To compare these formula-based figures with the actual results in the published opinions, I separately regress the damages awarded on Age and Age Squared for men and women. I then use the calculated coefficients to estimate the point values for various ages. ${ }^{33}$ As a comparison of Columns (1) and (2) with (3) and (4) shows, the values are close, generally within 5-10 million yen of each other. The observed mean values in Table 4 Column (4) are lower only because the published opinions include a large number of older victims (Table 2 Panel C).

The similarity between the ostensible formula-based figures in Table 8 Columns (1) and (2) and the actual regression-based point estimates in Columns (3) and (4) suggests two implications. First, these value-of-life estimates are not an artifact of publication-bias. Hypothetically, the private court reporters might have chosen to publish the opinions that awarded unusually high amounts. Instead, the judges in the published opinions awarded amounts that track the amounts predicted by the official formulae. Courts invoke the formulae as the proper way to value human lives; the regressions suggest they do what they say. ${ }^{34}$

33 I limit the regressions to wrongful-death cases yielding a plaintiff recovery, but not raising causation issues.

34 Note also that in Table 3 Col. (4), I report the mean amounts paid in all law suits (published and unpublished), as reported in Maeda, Sakamoto, \& Nobutomo (2001). These numbers are consistent with the mean amounts reported in the published opinions. 
102 predictable traffic-accident damage formula facilitated settlement in Japanese litigation. Maybe standardized judgments are routine in traffic accidents, some critics replied, but automobile accidents are exceptional (Foote, 1995; Riles \& Uchida, 2009: 8). If traffic accidents are exceptional, however, they are no more so than medical malpractice. There, judges use exactly the formula they use in traffic accidents - with the result, as Leflar (2009a: 445) put it, that once again the "predictability of damages aids pretrial settlement of cases."

\subsubsection{Anticipated value lives}

Because parties can use a decedent's earnings to predict the judgment, wrongful-death plaintiffs demand amounts that converge on the values judges eventually award (see Table 8 Panel C). For the most part, in wrongful death cases the judges value the decedents' lives at about 64 percent of what the plaintiffs initially demand. In five wrongful-death cases the judge awarded the plaintiffs exactly what they demanded, and in about 30 percent the judge gave the plaintiffs at least 80 percent. In only four cases did the judge value the decedent's life at less than a fifth of what the plaintiff demanded. Obviously, most plaintiffs are not "adding zeros" to their claims.

\subsubsection{Universities and clinics}

Damages are especially high in cases against large university and government hospitals. According to Panel A of Table 9, the university hospitals paid a mean 63.7 million yen (about $\$ 640,000$ ) per case and the government hospitals paid 60.9 million. The private clinics paid only 34.7 million yen $(\$ 350,000)$. To hold the basic patient-level variables constant, in Table 9 Panel B I regress the amount awarded on, inter alia, the health-care institution involved. Because the omitted variable is Clinic, the coefficient on University Hospital indicates that courts award plaintiffs an additional 30 million yen in suits against a university hospital.

The high awards against university hospitals probably reflect the mix of patients and medical procedures involved. Where the university hospitals specialize in complex procedures involving critically ill patients, clinics largely offer routine services for well patients. For the most part, the same degree of negligence will generate greater damages at the former than the latter. 
Table 9. Institutional Differences

\begin{tabular}{|l|c|c|}
\hline \multicolumn{2}{|c|}{ A. Damage Awards } \\
\hline \multicolumn{3}{|c|}{ Mean Award } \\
\hline 1. All Cases: \\
\hline University hospital & 63.7 million yen \\
\hline Government hospital & 60.9 & 33 \\
\hline Red Cross hospital & 46.3 & 33 \\
\hline Other public hospital & 50.7 & 7 \\
\hline Private hospital & 50.1 & 17 \\
\hline Dental office & 1.3 & 52 \\
\hline Clinic & 34.7 & 4 \\
\hline
\end{tabular}

\section{Death Cases Only:}

\begin{tabular}{|l|c|c|}
\hline University hospital & 59.7 million yen & 19 \\
\hline Government hospital & 49.0 & 16 \\
\hline Red Cross hospital & 58.0 & 4 \\
\hline Other public hospital & 47.7 & 13 \\
\hline Private hospital & 52.5 & 36 \\
\hline Dental office & & 0 \\
\hline Clinic & 41.4 & 15 \\
\hline
\end{tabular}

Notes: Table includes only those cases where plaintiff receives some amount, and where court does not dock amount for either comparative negligence or causation.

\begin{tabular}{|l|c|c|c|c|}
\hline \multicolumn{5}{|c|}{ B. Regressions } \\
\hline $\begin{array}{l}\text { Dependent } \\
\text { Variable: }\end{array}$ & $\begin{array}{c}\text { Plaintiff } \\
\text { Recovers }\end{array}$ & Award Value & Award Value & $\begin{array}{c}\text { File-to- } \\
\text { Judgment }\end{array}$ \\
\hline $\begin{array}{l}\text { University } \\
\text { Hosp }\end{array}$ & $-.328(1.24)$ & $30.4(3.94)^{\star \star \star}$ & $12.7(1.47)$ & $.430(1.03)$ \\
\hline $\begin{array}{l}\text { Government } \\
\text { Hosp }\end{array}$ & $-.240(0.92)$ & $19.7(2.65)^{\star \star \star}$ & $5.11(0.61)$ & $.883(2.14)^{\star \star}$ \\
\hline $\begin{array}{l}\text { Red Cross } \\
\text { Hosp }\end{array}$ & $-.291(0.71)$ & $3.25(0.25)$ & $4.79(0.32)$ & $-.266(0.37)$ \\
\hline $\begin{array}{l}\text { Other Public } \\
\text { Hosp }\end{array}$ & $-.260(0.90)$ & $15.2(1.73)^{\star}$ & $3.62(0.41)$ & $.077(0.17)$ \\
\hline Private Hosp & $.085(0.32)$ & $1.38(1.95)^{\star}$ & $4.69(0.60)$ & $.170(0.43)$ \\
\hline Dental Office & $-1.110(1.20)$ & $-42.3(1.15)$ & Dropped & $-2.48(1.26)$ \\
\hline
\end{tabular}


Table 9. (Continued)

\begin{tabular}{|l|c|c|c|c|}
\hline \multicolumn{5}{|c|}{ B. Regressions } \\
\hline $\begin{array}{l}\text { Dependent } \\
\text { Variable: }\end{array}$ & $\begin{array}{c}\text { Plaintiff } \\
\text { Recovers }\end{array}$ & Award Value & Award Value & $\begin{array}{c}\text { File-to- } \\
\text { Judgment }\end{array}$ \\
\hline Male & $.070(0.42)$ & $12.4(2.52)^{\star \star}$ & $14.7(2.81)^{\star \star \star}$ & $.236(0.90)$ \\
\hline Age & $.024(2.21)^{\star \star}$ & $.066(0.19)$ & $.849(2.31)^{\star \star}$ & $-.012(0.65)$ \\
\hline Age Sq & -.0003 & $-.007(1.56)$ & $-.014(2.84)^{\star \star \star}$ & $-.0000(0.18)$ \\
\hline Death & $-.192(1.12)$ & $-7.02(1.43)$ & & $.309(1.13)$ \\
\hline No Causation & & $-29.3(5.38)^{\star \star \star}$ & $-32.2(5.61)^{\star \star \star}$ & $.450(1.39)$ \\
\hline Pltf Recovers & & & & $-.018(0.06)$ \\
\hline Demand Value & & & & $4.64 @(1.88)^{\star \star}$ \\
\hline N & 310 & 239 & 142 & 237 \\
\hline Adj/pseudo R & .04 & .24 & .27 & .007 \\
\hline Regression & Probit & OLS & OLS & OLS \\
\hline Cases & & All Awards & Death Awards & \\
\hline
\end{tabular}

Notes: ${ }^{\star \star \star},{ }^{\star \star},{ }^{*}$ : significant at $1 \%, 5 \%$, and $10 \%$ levels. Column (1) are divided by $10^{6}$, and dataset in (2) and (3) is limited to Pltf Recovers =1. Column (2) includes all awards; Column (3) includes only wrongful-death cases. Published opinion dataset, as described in text. @ is $\times 10^{9}$.

Sources: Published opinion data base, as described in the text.

Yet even among wrongful-death claims, the courts award higher damages against university and government hospitals. According to Table 9 Panel A, in wrongful-death cases these hospitals paid 59.7 and 49.0 million yen respectively. The clinics paid only 41.4 million yen.

The same phenomenon appears in the Panel B regressions. Suppose I regress Award Value on the institutional variables, but limit the cases to those involving wrongful-death claims. The coefficient on University Hospital falls in magnitude and significance, but remains at 12.7 million yen. Given that the wrongful-death award represents (both officially and actually) forgone future earnings, university hospitals apparently serve a wealthier clientele than the clinics. Better educated patients tend to be richer than average, and-whether in the United States or Japan-tend to know when and how to obtain sophisticated care. ${ }^{35}$

35 Given that most medical schools are located in urban areas, one might have thought the significant coefficient merely reflected the higher wages in the cities. According to unreported regressions, however, the result is robust to the inclusion of geographical dummies. 


\subsection{Why Do Patients Sue their Best Doctors?}

\subsubsection{Introduction}

Why would Japanese patients disproportionately sue their best doctors rather than their worst? Why would they sue the specialists offering the most sophisticated care rather than the desultory clinic doctors peddling excessive antibiotics? I do not claim to offer a complete explanation. ${ }^{36}$ Paradoxically, however, patients sue the best doctors in part (a) precisely because they offer the most sophisticated care (Subsection 4.4.2, below); (b) because courts hold them to higher standards (Subsection 4.4.3); and (c) because they keep careful records to facilitate the teamwork involved (Subsection 4.4.4).

\subsubsection{They perform the most sophisticated work}

(a) Introduction. University hospitals specialize in the difficult, aggressive treatment of high-risk patients. They take people no one else can cure, and attempt complex, risky measures to save them. Among the obstetricians, for instance, those on the university staff take the high risk pregnancies; those in the private clinics take the "well babies." Among patients generally, the university hospitals take those needing the most aggressive procedures; the private clinics take healthy patients who want basic reassurance.

As the mean 36-day hospital-stay figures for Japan suggest (compared to 6.5 days for the United States; Ramseyer, 2009b: 312), moreover, many clinics (not university hospitals) function as long-term care facilities. They do not perform one difficult procedure after another. They do not rotate critically ill patients through their beds at American paces. They take old, mentally ill, and moderately sick patients and house them for weeks on end at government expense.

(b) More bad outcomes. That the university hospitals specialize in sophisticated care for the highest-risk patients generates two closely related consequences. First - the degree of negligence held constant-a higher fraction of cases at the university hospitals will result in "bad outcomes." Patients will not sue unless they experience an adverse event. Negligence or no, absent that adverse outcome they have no damages to collect. Even

36 Some readers of earlier drafts argued, for example, that patients may sue clinic doctors less often because they have closer, more personal ties with them. I have no evidence for or against this claim. 
among entirely non-negligent doctors, in other words, the one who treats the high-risk (i.e., sicker) patients will generate more bad outcomes than the one who caters to healthy patients. The point follows from the very definition of "high risk."

If patients could evaluate medical care accurately, they would not sue nonnegligent doctors who cause bad outcomes. But most patients cannot evaluate care accurately. They lack both the information and the expertise necessary to distinguish negligently-induced bad outcomes from simple bad luck. Lacking that information and expertise, they make both Type I and Type II errors: they forgive negligent doctors they should sue, and they sue non-negligent doctors they should thank. Even among the non-negligent doctors, therefore, patients will more often sue those offering sophisticated procedures to highrisk patients than those offering routine care to the fundamentally healthy.

Another way to phrase the point is that the less sophisticated procedures generate fewer bad outcomes that the patients can blame on their doctor. Clinic patients will not experience fewer bad outcomes. To the extent modern medical care improves patient welfare, they will experience more. They will, however, experience fewer they can blame on a doctor.

Suppose a patient has severe atherosclerosis. Suppose further that without a by-pass operation he will probably die. Although the operation increases the chance that he survives, it carries its own risks. It will not even necessarily save him. In the end, the preceding decades of fatty foods, indolence, and stressful work may kill him anyway.

Suppose the patient does not receive a by-pass, and dies. Not having had the operation, his heirs cannot attribute the death to a doctor. But suppose instead he has the by-pass. He may live-but only "may." He still may die, and if he does, his heirs can now plausibly blame his doctor for the death. By-pass operations may save lives, in other words, but because of the risks they inherently present and the health of the patients who undergo them, they increase the number of adverse events patients can try to blame on their doctors.

Patients will only sue a doctor when they experience a bad outcome that they can attribute to a doctor or hospital. Through its pricing structure, the Japanese insurance system discourages physicians and hospitals from offering intrusive procedures to seriously ill, high-risk patients. Necessarily, it reduces the number of adverse events for which patients can try to hold doctors and hospitals responsible.

(c) More negligence. Second, physicians performing more complex procedures may cause more genuinely negligent injuries. In part, this is 
because the coordination necessary for teamwork itself adds an easily identifiable potential error (Mello \& Studdert, 2008). But Mark Grady (1988) offered another reason not specific to Japan. ${ }^{37}$ Suppose a doctor lets his mind wander for 30 seconds. If a clinic internist does so while seeing a local patient, he may miss some symptoms. If he catches his slip, he will simply ask the questions again. If he misses his slip, he may misdiagnose the patient and prescribe the wrong antibiotic. But given that most people recover from most illnesses anyway, the patient will probably never notice.

Similarly, suppose a clinic surgeon lets his mind wander while setting a broken tibia. Usually, the bone will still heal. Sometimes, the surgeon may have to re-set it, but most patients will never know why. And if the improperly set bone does cause some residual pain, most patients will "live with it" rather than try to determine whether the doctor caused it negligently.

Suppose, however, that a thoracic surgeon lets his mind wander in the course of a CABG operation. Or suppose a neurosurgeon lets his mind wander while cauterizing a blood vessel in a patient's brain. Some patients will find themselves disabled for life. Others will die. In effect, the technological sophistication of the procedure will transform the same routine (and usually harmless) human fault, a wandering mind, into legal negligence, and massively increase the costs to the patient. ${ }^{38}$

\subsubsection{Courts hold them to higher standards}

Japanese courts hold sophisticated physicians and institutions to higher levels of care than the levels they impose on the clinic doctors. The higher the quality of the institution and the greater the expertise of the physician, the higher the level of care the court will demand. And the higher the quality of care available in a community, the higher the standard to which

37 And explicated further in Grady (2009: 179, 213-218) ("negligent accidents usually become more common, not less, when safety technology becomes better"). This and related themes have been explored insightfully by several other scholars as well. See, e.g., Sage (2003); Jacobson (2006: 118) ("precision of new technologies means that momentary lapses or minor mistakes can have serious consequences”).

38 As Grady (2009: 218) put it: "Paradoxically, claims for negligent appendectomies will be stronger in the twenty-first century than they were in the nineteenth century, even when safety technology is better today and today's overall safety investments are larger than they were in the nineteenth century. The better safety technology itself causes increased negligent behavior-not just increased findings of negligence, but increased rates of negligence itself." 
courts will hold physicians in that community. As the Supreme Court put it in $1995:^{39}$

When a new method of treatment has been developed, should it (the tests, examination, treatment, etc.) be demanded of a medical institution? One cannot make the decision without considering the character of the medical institution, the medical environment of the area in which the institution is located, and so forth. It is not appropriate to ignore these factors and impose ... a uniform medical standard on all medical institutions. (2007: 327) explains:

In the [1995 Supreme Court] case, a hospital providing a high level of care was the defendant. Yet the diffusion of new treatment methods proceeds at different speeds depending on "the character of the medical institution [and] the medical environment of the area in which the institution is located." As a result, the presence of a violation of the duty of care should be determined by taking all of the factors into consideration.

\subsubsection{They produce more transparent records}

122

Because the large hospitals offer their care through teams, they necessarily need to keep fuller, more transparent records. They keep these documents to facilitate the coordination necessary among specialists (coordination failures are themselves a source of legal negligence), but the more transparent records also enable plaintiffs after the fact to identify any mishaps. Because doctors in clinics and small hospitals supply most of the care themselves, they have less reason to keep transparent records. And if more transparent records facilitate litigation, then all the more reason to keep any records cryptic.

Indeed, should a clinic doctor want to "scrub" a patient's medical records after the fact, sometimes no one will prevent him (or her) from doing this either. One legal handbook for doctors makes the point explicit (Inoue, 2007: 88). Suppose, it suggests, that you are asked to disclose:

39 Kono v. Nihon sekijuji sha, 1537 Hanrei jiho 3, 7 (Sup. Ct. June 9, 1995) (ital. added). That the standard of care varies by institutional character and geography is not peculiar to the 1995 case. Other opinions making the same point include: Kono v. Iryo hojin Ijinkai, 1734 Hanrei jiho 90, 100-01 (Nagoya D. Ct. Apr. 8, 1999) (finding liability); Yokozawa v. Japan, 1271 Hanrei jiho 3, 427 (Tokyo High Ct. Mar. 11, 1988) (finding liability); Ikemoto v. Kitakyushu, 1265 Hanrei jiho 75, 76 (S. Ct. Jan. 19, 1988) (Ito, J., concurring) (no liability); Hiranuma v. Tanaka, 1236 Hanrei jiho 105, 110 (Osaka D. Ct. June 12, 1986) (no liability). 
a complete set of the original medical records such as the patient's medical chart.... When you receive that disclosure request, you should first check the entire document. If you find a mistake, you should correct it. If you find matters only inadequately noted, you should add the necessary material.

Legal? In a handbook for potential plaintiffs, one lawyer understandably implies that it approaches fraud (Ueda, 2007: 117-125). He recognizes that it commonly happens, however, and details ways to detect it.

Reflecting a patient's inability to learn of physician error in a small clinic, the published-opinion database contains almost no successful claims against a clinic-where the patient ended his medical care there. Instead, virtually the only claims against the clinics that appear are those where the patient began his (or her) care at the negligent clinic, but then moved to a second institution. More precisely, in 43 of the 51 cases where a plaintiff recovered damages from a clinic, the patient moved from the negligent clinic to a hospital that could then testify to what initially happened in the clinic.

The logic is simple. Suppose a clinic doctor botches an operation, and realizes he (or she) cannot handle the situation. Reluctantly but conscientiously, he (or she) calls an ambulance. The ambulance rushes the patient to the municipal hospital, where the more sophisticated specialists do their best to save him. If the patient dies anyway, his family may (no doubt sometimes the hospital staff hesitate to "rat" on the clinic doctors) hear all about the erring clinic doctor from the hospital staff.

By contrast, suppose the clinic doctor botches an operation but does not bother to call an ambulance. He (or she) knows he (or she) cannot handle the situation, but would prefer no one else learn of his (or her) mistake. Rather than rush the patient to the hospital, the doctor just lets the patient die. The patient's heirs will have far less access to any information they would need to file a suit.

In the Japanese court opinions, heirs sometimes sue the conscientious doctor who calls the ambulance. The doctor who lets the patient die, they virtually never do.

\section{OVERALL CLAIMING LEVELS}

\subsection{Estimating from Insurance Premia}

Insurance premia offer one way to estimate the amounts that claimants recover. Regulated, to be sure, the Japanese casualty insurance market is 
competitive. And in competitive markets, insurers will set their premia at levels that let them recover their expected liabilities and administrative costs. ${ }^{40}$

Doctors who operate private clinics can buy personal malpractice coverage through the JMA for 70,000 yen. ${ }^{41}$ They can add institutional coverage through casualty insurance firms at rates estimated at 30,000 yen per bed (Leflar, 2009b: 8 n.28). And staff doctors can purchase coverage at rates advertised (in mid-2009) at 40,000 to 60,000 yen. Because Japanese hospital physicians work as employees rather than (as often in the U.S.) independent contractors, the hospital is liable for the doctor's torts under respondeat superior. As a result, the hospital's resources are crucial.

Compared to liability premia in the U.S., these rates are low. ${ }^{42}$ U.S. insurers charge prices that vary widely by specialty, but even in the cheapest fields they exceed these numbers. In internal medicine, U.S. insurers charge \$10,000-\$20,000. In obstetrics and gynecology, they charge $\$ 50,000-\$ 90,000$. Across all fields, they charge a mean of about $\$ 18,400$ (2000 data; Sloan \& Chepke, 2008: 59, 60 fig. 3.1).

From these revenues, insurers will expect to cover their liabilities and operational costs. By one insurance text, Japanese casualty insurers distribute about 55 percent of their premium revenue to claimants (Takimoto, 1994: 171). According to its 2008 disclosure filings, Sonpo Japan (insurer to hospitals and physicians) distributes about 60 percent of its revenues (Sonpo Japan, 2008).

If all doctors and hospitals bought insurance at these rates, malpractice revenues would total:

\begin{tabular}{lc} 
Clinic doctors, at 70,000 yen: & 4,958 million yen \\
Staff doctors, at 50,000 yen: & 9,292 million \\
Beds, at 30,000 yen: & 54,383 million \\
\hline Total: & 68,633 million yen
\end{tabular}

If insurers paid the full amount to claimants, they thus would pay 69 billion yen (about $\$ 690$ million). If they paid only 55 percent, they would pay

40 Subject, of course, to qualifications relating to such factors as the insurance underwriting cycle. For such reasons, the relation between premiums and payouts in the United States has sometimes been hard to demonstrate.

41 About \$700. See Leflar (2009a, 2009b). This contract pays up to 100 million yen, subject to a 1 million yen deductible.

42 They are also much more stable. Given the low claiming levels, Japanese premiums are not subject to the fluctuations found in the United States. 
38 billion. ${ }^{43}$ Recall that Mello \& Studdert (2006) estimate the total U.S. (with 2.5 times the Japanese population) liability at $\$ 5.8$ billion. Wheat (2005) estimates the U.K. (with about half the Japanese population) liability at $\$ 642$ million. Apparently, Japanese claimants collect per capita about 16 to 29 percent as much as American claimants, and about 27 to 50 percent as much as U.K. claimants.

Only apparently-because this estimate is low. The calculation totals premium revenues_-based on the prices charged clinics. But as the discussion above shows, Japanese patients do not primarily sue the clinics. Disproportionately, they sue the large university and public hospitals. For the most part, these institutions simply self-insure. If university doctors were to buy third-party insurance on the market, they obviously would pay much higher prices than those the JMA charges their compatriots in the clinics.

For the same reason, the 30,000 yen per bed charge underestimates institutional liabilities. Clinics may pay 30,000 yen per bed, but patients do not sue them. They do sue the university hospitals, and rational insurers would never sell them coverage at 30,000 yen per bed. Rather than pay higher prices, the hospitals pay claims out of their operating budgets.

\subsection{Estimating from Court Claims}

The published opinions offer an equally tentative way to estimate total claiming levels. First, during the seven years from 1998 to 2004, plaintiffs filed claims that yielded 229 published opinions (Table 1 Panel A). Among these plaintiffs, those in 182 cases (using Table 1 Panel B and Table 4) recovered 8.4 billion yen: a mean recovery of 36.5 million yen on all cases, and 46.0 million yen per victorious case. ${ }^{44}$

Second, during the same seven-year period, claimants litigated 2,298 (published and unpublished) malpractice cases to judgment. In these cases, 931 plaintiffs recovered some amount:

Litigated to judgment: 2,298 cases over 7 years (328/year), with plaintiffs recovering some amount in 931 cases (133/year).

43 Similarly aggregating physician and hospital premia, Kodama (2007: 74) estimates total malpractice payments in Japan at 50 billion yen.

44 Maeda, Sakamoto, \& Nobutomo (2001: 58) and Hagihara, Nishi, \& Nobutomo (2003: 121) seem to report 22.0 million yen and 7.6 million yen, respectively, as the mean payouts for 1986-1998, despite purportedly using the same database. 
139

Additionally, claimants filed another 3,174 cases that did not proceed to judgment.

By combining these observations, I can estimate an upper-bound to the total recovery in litigated malpractice claims. Recall that the 182 successful published-opinion plaintiffs recovered 8.4 billion yen. If the remaining $(931-182=) 749$ successful litigating plaintiffs recovered the same average amount, ${ }^{45}$ they would have collected $(749 \times 46.0$ million yen $=) 36.8$ billion yen.

Turn then to the plaintiffs in the 3,174 cases from 1998 to 2004 who settled or were dropped. Suppose that these plaintiffs succeeded at the same rates as those who litigated to judgment (Table 1 Panel B).

Filed but settled: 3,174 cases over 7 years (453/year), with estimated recoveries in 1,286 cases (184/year).

If the successful claimants collected the same average amounts as those in the published-opinion cases, they would have recovered an additional $(1,286 \times 46.0$ million $=) 59.2$ billion yen. Alternatively, suppose (as seems more likely) that the settling claimants discounted their claims by the expected probability of success. If so, then more of them would have recovered something, but each would have received less. Given rational expectations, defendants would have paid the same aggregate amount. ${ }^{46}$

By coupling the insurance-based estimates in Subsection 5.1 with these court-claims-based estimates, I can also calculate the number of claimants who settled without first filing suit. Over seven years, defendants paid to the suing plaintiffs:

Actual amount to published-opinion plaintiffs:

8.4 billion yen Estimated amount to unpublished opinion plaintiffs: $\quad 36.8$ billion yen Estimated amount to settling plaintiffs: 59.2 billion yen Total: 104.4 billion yen

45 Table 1 Panel A indicates that these cases involved shorter times to judgment. In turn, this suggests that the plaintiffs in the unpublished cases probably raised lower stakes and recovered lesser amounts.

46 For example, suppose 100 claimants file suits for $\$ 5000$, and each has a 20 percent chance of success. If all parties settle at the expected value of their claim, the defendants will pay $\$ 100,000:(.2 \times 5000=) \$ 1000$ to all 100 claimants. If instead all parties litigated to judgment, the defendant would still pay $\$ 100,000: \$ 5000$ to $(100 \times .2=) 20$ claimants. 
Per year, defendants paid $(104.4 / 7=) 14.9$ billion yen. The subsection 5.1 insurance-based estimates suggest a one-year total payout of 37.7 to 68.6 billion yen. Less the 14.9 billion to the filing plaintiffs, the defendants must pay 22.8 to 53.7 billion yen per year to the non-filing (i.e., not filing a claim in court) claimants.

Furthermore, suppose defendants paid the non-filing claimants average amounts equal to those they paid the published-opinion plaintiffs (36.5 million yen per plaintiff). Per year, they would have settled with $(22,800 / 37.7=) 625$ to $(53,700 / 37.7=) 1,471$ non-filing claimants. If they paid the non-filing claimants less (e.g., if, as seems reasonable, the non-filing patients asserted smaller claims), they would have paid more claimants.

Based on Table 1 figures for 2004, these calculations yield a total collecting (in- or out-of-court) claimant estimate of:

Litigating plaintiffs $(405 \times .395)$ : $\quad 160$

Filed but settling plaintiffs $(1,004-405): \quad 599$

\begin{tabular}{ll} 
Non-filing claimants: & 1,471 \\
\hline Total claimants: & 2,230
\end{tabular}

Recall, however, that these estimates are low. The actually targeted doctors almost surely pay more than the premia charged the JMA clinic doctors.

As an alternative approach, I can discount the litigated cases by more general estimates of the number of out-of-court claims. ${ }^{47}$ Nakajima et al. (2001: 1635), for example, suggest that Japanese claimants litigate 8 percent of all malpractice claims; Sasao et al. (2006: 1953) puts the figure at 10 percent. If plaintiffs annually file 1,110 claims in court, claimants may assert (in and out of court) as many as $1,110 / .08=13,875$ claims per year.

All told, the claim-based approach suggests a wide range: 1,004 litigated claims per year, but between 2,230 and 13,875 total claims per year. As two benchmarks, recall that Mello \& Studdert (2006: 13) estimate 50,000-60,000 paid claims a year in the United States. In Canada

47 Leflar \& Iwata (2005) and Ramseyer \& Nakazato (1999) also extrapolate from the number of settlements negotiated through the prefectural medical associations. Unfortunately, this introduces the same bias as the premium-based estimates. The prefectural medical associations only handle the claims against association members-overwhelmingly clinic doctors. 
(with one-third the Japanese population), claimants file 1,083 suits (CHSRF, 2006).

\section{WHY ARE CLAIMING LEVELS SO LOW?}

\subsection{Unfounded Explanations}

\subsubsection{Introduction}

Apparently, claiming levels in Japan are not egregiously low, but they are low nonetheless. To explain these claiming levels, observers to date have advanced several explanations. Consider each in turn.

\subsubsection{Attorney-driven explanations}

(a) Fee structure. Several observers (e.g., Feldman, 2009: 264; Yasunaga, 2008; Leflar, 2009a; Maeda, Sakamoto, \& Nobutomo, 2001) argue that the traditional Japanese fee schedule discourages malpractice claims. Under this schedule, clients initially pay their attorney a fraction of the amount they demand as a nonrefundable retainer. Should they successfully recover, they later pay him an additional fraction of the amount actually collected. Many malpractice victims, these scholars explain, simply lack the cash to advance their lawyer the initial payment.

As an explanation for the low claiming levels, however, this schedulebased argument does not work. Crucially, these observers do not argue that attorneys charge too much. Rather, they argue that attorneys structure their fee according to a format that does not fit the market.

The explanation fails because the fee schedule has never been more than a suggestion, ${ }^{48}$ and in some sectors (like the Tokyo international market) it has been a routinely ignored suggestion. Had a different schedule with the same expected value maximized the joint welfare of an attorney and potential client, they could and would have freely chosen it. And if a client with a positive expected value claim needed a high-risk loan (the essence of a contingent fee) that the attorney could not make, he could have borrowed the money elsewhere and paid the attorney in cash. ${ }^{49}$

48 As some who posit this as an explanation acknowledge. See Feldman (2009: 264).

49 Whether the parties actually ignored the suggested fee structure is not the issue; the crucial question is whether they could. If indeed they could ignore it but they did not, that fact simply suggests that the structure suited the mutual interests of the attorney and client. 
(b) Number of Attorneys. For clients, the problem in Japan has not involved (logically, could not have involved) the fee structure. Instead, it has involved the fee level. Put most directly, attorneys have simply charged more for their services than some malpractice claims warranted.

Evidence that fee levels have priced some malpractice claimants out of the market appears in Table 10. Attorney prices are a function (in part) of supply: the number of attorneys per capita. In Column (1), I regress malpractice suits per prefecture on the standard independent variables and the number of attorneys in the prefecture. Because this number is endogenous to the level of litigation, I instrument it by the level of amenities available to professional families in the area. This is the approach used in Nakazato, Ramseyer, \& Rasmusen (2010) to instrument the number of attorneys in their study of prefecture-level attorney incomes. The calculated coefficient on the number of attorneys is positive and significant: the more attorneys per prefecture, the more malpractice suits.

The result for attorneys is robust. Because half of Japanese attorneys work in Tokyo (Nakazato, Ramseyer, \& Rasmusen, 2010) and file the plurality of all malpractice suits, Tokyo could be driving the results. In Column (2) I drop Tokyo, and the coefficient on attorneys remains strongly significant, though the other coefficients lose significance. In Column (3) I include the CABG variable, and in Column (4) I run the regression in OLS. In both cases, the coefficient on the number of attorneys remains positive and significant.

This positive coefficient on the number of attorneys suggests that attorneys probably consider malpractice litigation undesirable work. Rational attorneys will take first the projects paying the highest returns, and move to lower-return projects only on a time-available basis. Infra-marginal, the highest return projects will be insensitive to the number of attorneys; the lowest return projects will not be, and according to Table 10 malpractice litigation is not. Instead, the more attorneys in the area, the more malpractice suits filed. Tentatively to be sure, the regressions suggest that attorneys take malpractice cases only when they lack enough other work.

Consistent with this observation, recall that plaintiffs disproportionately file malpractice suits in Tokyo and Osaka (Table 1 Panel C). Because these cities offer the greatest amenities for professional families, they attract the most attorneys. And because of the resulting competition, the attorneys in these prefectures (other than the few in the international law firms) earn lower incomes than they could earn elsewhere (Nakazato, Ramseyer, \& 
Table 10. Malpractice Suits and Attorneys

\begin{tabular}{|l|c|c|c|c|}
\hline & (1) & (2) & (3) & (4) \\
\hline \multicolumn{5}{|l|}{ Dependent variable: Suits } \\
\hline Population & $-.000(0.23)$ & $.000(0.49)$ & $-.000(1.74)^{\star}$ & $.000(1.75)^{\star}$ \\
\hline Hospital Beds & $.0002(3.15)^{\star \star \star}$ & $-.000(0.59)$ & $.0002(3.09)^{\star \star \star}$ & $.0002(3.12)^{\star \star \star}$ \\
\hline Clinic Beds & $\begin{array}{l}-.001 \\
(2.56)^{\star \star}\end{array}$ & $.000(0.57)$ & $-.001(2.89)^{\star \star \star}$ & $-.001(3.15)^{\star \star \star}$ \\
\hline $\begin{array}{l}\text { Cardiac } \\
\text { By-pass }\end{array}$ & & & $1.018(2.06)^{\star \star}$ & $.946(2.84)^{\star \star \star}$ \\
\hline Attorneys & $.008(5.01)^{\star \star \star}$ & $.022(4.55)^{\star \star \star}$ & $.008(5.22)^{\star \star \star}$ & $.008(17.44)^{\star \star \star}$ \\
\hline$n$ & 46 & 45 & 46 & 46 \\
\hline Adj R & .96 & .94 & .97 & .97 \\
\hline Regression & 2 SLS & 2 SLS & 2 SLS & OLS \\
\hline Prefectures & All & Ex Tokyo & All & All \\
\hline
\end{tabular}

Notes: ${ }^{\star \star \star},{ }^{\star \star},{ }^{\star}$ : statistically significant at the 1,5 , and $10 \%$ levels.

Coefficients, followed by the absolute value of the $t$-statistic on the line below. Population coefficients are $\times 10^{7}$. All regressions include a constant term. All prefectures except Okinawa, excluded because of its idiosyncratic legal market.

Attorneys are instrumented with variables indicating the amenities available to professional families in the prefecture: Museums, Concerts, School Internet, and College Grads.

Rasmusen, 2010). Again, attorneys apparently turn to malpractice only when clients offer insufficient better-paying work.

\subsubsection{Cultural explanations}

In a workshop on an earlier version of this paper, readers suggested that the Japanese patterns of malpractice litigation might reflect distinctive aspects of Japanese culture. Concerns over culture pervade comparative litigation research-indeed, even domestically. De Ville (1998: 199) argues that:

Potential litigants are constrained by more than just legal rules. Cultural and community attitudes, habits, and customs define socially acceptable ways to deal with grievances.... [W] hen people live in tightly knit, kinship-based corporate communities, the social costs of disrupting the order are greater and litigation is relied upon less frequently....

To test this and similar propositions, I offer several prefecture-level regressions (Table 11). To capture the possibility that litigation might be a "non-traditional" strategy shunned by older members of the community, in Column (1) I add the percentage of the population over age 64. The 
Table 11. "Cultural" Factors

\begin{tabular}{|c|c|c|c|c|c|}
\hline & (1) & (2) & (3) & (4) & (5) \\
\hline \multicolumn{6}{|c|}{ Dependent variable: Suits } \\
\hline Population & $\begin{array}{l}-.000 \\
(1.23)\end{array}$ & $\begin{array}{l}-.000001 \\
(1.77)^{\star}\end{array}$ & $\begin{array}{l}-.000002 \\
(3.26)^{\star \star \star}\end{array}$ & $\begin{array}{l}-.000001 \\
(1.76)^{\star}\end{array}$ & $\begin{array}{l}-.000002 \\
(2.93)^{\star \star \star}\end{array}$ \\
\hline Hospital Beds & $\begin{array}{c}.0002 \\
(3.01)^{\star \star \star}\end{array}$ & $\begin{array}{c}.0002 \\
(2.95)^{\star \star \star}\end{array}$ & $\begin{array}{c}.0002 \\
(3.78)^{\star \star \star}\end{array}$ & $\begin{array}{c}.0002 \\
(3.00)^{\star \star \star}\end{array}$ & $\begin{array}{c}.0002 \\
(3.80)^{\star \star \star}\end{array}$ \\
\hline Clinic Beds & $\begin{array}{l}-.001 \\
(2.67)^{\star \star}\end{array}$ & $\begin{array}{l}-.001 \\
(2.23)^{\star \star}\end{array}$ & $\begin{array}{l}-.001 \\
(2.05)^{\star \star \star}\end{array}$ & $\begin{array}{l}-.001 \\
(2.99)^{\star \star \star}\end{array}$ & $\begin{array}{l}-.0003 \\
(1.05)\end{array}$ \\
\hline $\begin{array}{l}\text { Cardiac } \\
\text { By-pass }\end{array}$ & $\begin{array}{c}.946 \\
(1.80)^{\star}\end{array}$ & $\begin{array}{c}1.077 \\
(2.12)^{\star \star}\end{array}$ & $\begin{array}{c}.793 \\
(2.14)^{\star \star}\end{array}$ & $\begin{array}{c}.939 \\
(2.52)^{\star \star}\end{array}$ & $\begin{array}{r}.351 \\
(1.06)\end{array}$ \\
\hline Attorneys & $\begin{array}{c}.008 \\
(4.35)^{\star \star \star}\end{array}$ & $\begin{array}{c}.007 \\
(4.97)^{\star \star \star}\end{array}$ & $\begin{array}{c}.005 \\
(2.88)^{\star \star \star}\end{array}$ & $\begin{array}{c}.009 \\
(6.40)^{\star \star \star}\end{array}$ & $\begin{array}{c}.006 \\
(4.72)^{\star \star \star}\end{array}$ \\
\hline$\%$ Over 64 & $\begin{array}{l}-.030 \\
(0.06)\end{array}$ & & & & $\begin{array}{r}.129 \\
(0.48)\end{array}$ \\
\hline$\%$ Agricul Eco & & $\begin{array}{l}-.029 \\
(0.87)\end{array}$ & & & $\begin{array}{l}-.015 \\
(0.51)\end{array}$ \\
\hline Density & & & $\begin{array}{c}.006 \\
(2.64)^{\star \star}\end{array}$ & & $\begin{array}{c}.006 \\
(4.12)^{\star \star \star}\end{array}$ \\
\hline GDP PC & & & & $\begin{array}{r}-1067 \\
\quad(0.48)\end{array}$ & $\begin{array}{l}2607 \\
\quad(1.34)\end{array}$ \\
\hline$n$ & 46 & 46 & 46 & 46 & 46 \\
\hline Adj $R^{2}$ & .97 & .97 & .97 & .97 & .98 \\
\hline
\end{tabular}

Notes: ${ }^{\star \star \star},{ }^{\star *},{ }^{*}$ : statistically significant at the 1,5 , and $10 \%$ levels.

Coefficients, followed by the absolute value of the $t$-statistic on the line below. All regressions include a constant term. All prefectures except Okinawa, excluded because of its idiosyncratic legal market.

Attorneys are instrumented with variables indicating the amenities available to professional families in the prefecture: Museums, Concerts, School Internet, and College Grads.

Sources: Published opinion data base, as described in the text.

coefficient is insignificant. To capture the possibility that farm communities might be more "traditional," in Column (2) I add the percentage of the economic output that is agricultural. Again, the coefficient is insignificant.

De Ville (1998) suggests that litigation patterns will depend on whether the community is tightly knit. Column (3) suggests mixed results: the coefficient on the population itself is negative, but the coefficient on the population density is positive. The former result is inconsistent with 
the notion that more traditional communities forestall litigation; the latter is consistent with it. The more people in a prefecture, the fewer suits filed, but the more people per square kilometer, the more suits filed. To explore the possibility that wealthier communities might be less traditional, in Column (4) I add GDP per capita. The coefficient is insignificant. And in Column (5) I add all four "cultural" variables: other than on Density, the coefficients are again insignificant.

Perhaps the strongest evidence against the notion that cultural norms seriously constrain malpractice claiming, however, lies in the very litigation one observes: Japanese claimants most readily sue university physicians. Among all professionals in Japan, cultural norms assign no one greater respect than the university professor. Whether on prestige, honor, or moral authority, no other physicians approach the respect that Japanese cultural norms grant university hospital physicians. If those norms protected anyone, they would protect the professor. Yet patients do not sue the more plebian, far-less-respected local clinic doctors. They sue their university professors.

Advocates of a cultural approach could change the hypothesis, of course. Perhaps cultural norms protect only local community members, not the distant and unapproachable professor. Held to a higher standard, perhaps the university professor faces stronger sanctions for any failings. Yet to suggest such changes is to highlight the essentially non-testable nature of this approach. Given the data, one can always tell a culture-based story that "explains" it. But as Talcott Parsons pointed out, the approach is as circular as they come (Geertz, 1973: 249-250): To explain the way people behave as a product of their culture, while defining culture as the way they have learned to behave does not, he is said to have told generations of students ... get us very far.

\subsubsection{Court structure}

(a) Delays. Scholars (Yasunaga, 2008; Feldman, 2009: 269; Maeda, Sakamoto, \& Nobutomo, 2001) also attribute the scarcity of malpractice claims in Japan to the length of the court proceedings. ${ }^{50}$ Malpractice

50 Leflar (2009a: 444-445) rightly notes that delays in Japan were substantial only before the recent reforms. In attributing the low claiming levels to delays, however, other observers draw on a tradition in American scholarship that blames low Japanese litigation rates in part on court delays (Haley, 1978). As the discussion here shows, Japanese courts are not particularly slow. See also Ramseyer \& Nakazato (1999: 140-141). 
cases do take time. Where Japanese civil suits take a mean 8.4 months from filing to judgment (Inoue, 2007 35), malpractice suits take 2.3 years. In Table 12 Panel A, I compare the published-opinion malpractice cases against a random sample of 120 published-opinion civil damage suits from 1995 to 2004, with equal numbers of cases per year (generally one per month). Where the random civil case takes 2.3 years, the malpractice suit takes 4.3 years. When I regress filing-to-judgment on the usual independent variables with the pooled malpractice-civil-damage dataset, the coefficient on the malpractice dummy is positive and statistically significant (Table 12 Panel B). Consistent with the two-year difference in means (Panel A), the coefficient on the malpractice dummy is about 2.

Malpractice claims take longer even with the amount at stake held constant. According to Panel A of Table 12, malpractice plaintiffs demanded an average 59 million yen. Plaintiffs in civil damage suits claimed only 31 million yen. And higher-stakes suits do take longer: the coefficient on Demand Value in the pooled dataset regression is positive and significant (Table 12 Panel B). With Demand Value held constant, however, the coefficient on the malpractice dataset variable remains significant.

Even if court delays explain part of the reason Japanese less readily file claims over malpractice than over traffic accidents (if indeed they do; I take no position on the question), they hardly explain why Japanese file fewer malpractice claims than Americans. According to the NPPB, incident-to-judgment times in the U.S. average 4.7 years. The Japanese courts disclose only filing-to-judgment times, but in Japanese malpractice cases these average 2.3 years. ${ }^{51}$ In the published-opinion database, the difference between incident- and filing-to-judgment times averaged 1.6 years. If I add the 1.6-year difference to the mean filing-to-judgment times of 2.3 years, I still obtain average incident-to-judgment times in Japan of only 3.9 years. Malpractice litigation may take time in Japan, in short, but it is still faster than in the United States.

(b) Burden of proof. Feldman (2009: 263-264) also blames the apparent reluctance of Japanese patients to sue on the way courts require them to bear the burden of proof: Japanese courts require them to "prove the central elements of their allegations." At a couple of levels, this fundamentally misleads. First, that the Japanese courts require plaintiffs to prove

51 I exclude claims filed more than three years after the incident. These are primarily disability claims filed after the patient was certified by the government as disabled. 
Table 12. Court Delays

\begin{tabular}{|l|c|c|c|c|c|}
\hline \multicolumn{7}{|l|}{ A. Summary Statistics } \\
\hline Dataset & $n$ & Min & Median & Mean & Max \\
\hline 1. Filing to Judgment (years): & 343 & 0 & 4 & 4.29 & 11 \\
\hline Malpractice cases & 120 & 0 & 2 & 2.34 & 11 \\
\hline Random civil cases & \multicolumn{7}{|l}{} \\
\hline 2. Amount Demanded (million yen): \\
\hline Malpractice cases & 338 & .589 & 59.4 & 74.4 & 546 \\
\hline Random civil cases & 120 & .388 & 31.4 & 71.3 & 674 \\
\hline
\end{tabular}

\begin{tabular}{|c|c|c|}
\hline \multicolumn{3}{|c|}{ B. Regressions } \\
\hline & (1) & (2) \\
\hline \multicolumn{3}{|c|}{ Dependent Variable: File-to-Judgment } \\
\hline Med Mal & $1.970(9.46)^{\star \star \star}$ & $1.891(4.80)^{\star \star \star}$ \\
\hline Demand Value:\# & $5.72(5.14)^{\star \star \star}$ & $5.50(4.90)^{\star \star \star}$ \\
\hline Tokyo & $-.867(3.77)^{\star \star \star}$ & $-.681(1.45)$ \\
\hline Osaka & $-.363(1.34)$ & $-.512(0.96)$ \\
\hline Nagoya & $.568(1.36)$ & $-.738(0.97)$ \\
\hline Yokohama & $-.649(1.35)$ & $-.227(0.12)$ \\
\hline Kobe & $.925(2.19)^{\star \star}$ & $.694(1.12)$ \\
\hline Fukuoka & $-.274(0.60)$ & $-.165(0.18)$ \\
\hline Shizuoka & $1.661(2.65)^{\star \star \star}$ & $2.948(1.51)$ \\
\hline MM * Tokyo & & $-.267(0.50)$ \\
\hline$M M *$ Osaka & & $.194(0.31)$ \\
\hline MM * Nagoya & & $1.903(2.09)^{\star \star}$ \\
\hline MM * Yokohama & & $-.435(0.22)$ \\
\hline$M M$ * Kobe & & $.455(0.52)$ \\
\hline MM * Fukuoka & & $-.145(0.14)$ \\
\hline MM * Shizuoka & & $-1.422(0.69)$ \\
\hline \multicolumn{3}{|l|}{ Post 2001} \\
\hline \multicolumn{3}{|l|}{ MM * Post 01} \\
\hline$n$ & 456 & 456 \\
\hline Adj $R^{2}$ & .25 & .25 \\
\hline
\end{tabular}

Notes: ${ }^{\star \star \star},{ }^{\star \star},{ }^{\star}$ : statistically significant at the 1,5 , and $10 \%$ levels.

Coefficients, followed by the absolute value of the $t$-statistic on the line below. All regressions include a constant term. $\#: \times 10^{9}$. "MM ${ }^{\star \prime}$ designates the interaction of the variable with a dummy variable equal to 1 if the case is from the medical malpractice dataset.

Sources: Published opinion data base, as described in the text. 
their case distinguishes malpractice claims neither from other Japanese civil cases, nor from malpractice claims in the United States. In most civil litigation in Japan, plaintiffs bear the burden of proof. In most civil litigation in the United States, including medical malpractice litigation, plaintiffs bear the burden of proof. That Japanese plaintiffs also bear the burden in malpractice cases explains nothing.

Second, just as American courts sometimes switch the burden of proof to defendants through doctrines like res ipsa loquitur, so do Japanese courts. As one court explained: ${ }^{52}$

The plaintiffs have neither asserted nor proven that the surgeon violated his duty of care. Yet the case involves the highly specialized field of medicine.... In such cases, a plaintiff must show (i) that there was a mishap in his procedure, and (ii) that his symptoms thereafter worsened. Once he does so, a court may properly infer both negligence and the resulting injury.

In some ways, Japanese plaintiffs in malpractice cases bear a lower burden of proof than in other civil claims.

(c) Levels of damages. Some scholars further attribute the low malpractice claiming levels to the more "modest" (relative to the United States) damages awarded in Japanese courts. ${ }^{53}$ According to the published-opinion database, however, Japanese courts award almost exactly the same average damages as American courts. As Leflar \& Iwata (2005) rightly observe, "mean and median awards in U.S. wrongful death cases ... seem not to diverge radically from the Japanese scale of damages." In wrongful-death claims, American courts award a decedent's heirs about \$200,000-\$300,000 (Section 1.1, above). Where causation is not an issue, Japanese courts award victorious plaintiffs in medical malpractice wrongful death cases a mean of about 50

52 Yamamoto v. Isami kotsu K.K., 485 Hanrei jiho 21, 25-26 (Tokyo D. Ct. June 7, 1967). In contesting this observation, Feldman (2009: 263) writes that the "Japanese academic commentary on the burden of proof in malpractice claims uniformly asserts" that "the burden of proof falls on plaintiffs." In fact, commentators routinely discuss the way Japanese courts shift burdens of proof to defendants in malpractice cases. Consider, for example, the standard civil law treatise by then-University of Tokyo Professor Takashi Uchida (2007: 328): in medical malpractice cases, courts sometimes "lighten the burden of proof through a method known as the presumption of negligence." He then elaborates on the point for over four pages. For other discussions of the issue, see, e.g., Azami \& Nakai (1994: 178-182), Kato (2005: 271-273), Nakamura (2001: 279-280).

53 Feldman (2009: 266-267). In making this claim, Feldman again reflects one tradition in U.S. scholarship. See note 50, above. This tradition identifies low court awards as one reason for low litigation levels generally. See, e.g., Haley (1978). 
million yen (Table 4) —at 100 yen per dollar, about $\$ 500,000$; including cases of less than full causation, they award about 40 million yen. ${ }^{54}$ Whatever the reason for the lower malpractice claiming levels in Japan, it is not modest damages.

\subsection{Alternative Hypotheses}

\subsubsection{Introduction}

Patients file relatively few malpractice claims in Japan (not extremely few, but fewer than in the United States and some other wealthy democracies), and this study suggests (even if it does not prove) a reason why. I do not explore the question directly. I do not collect data on all medical procedures. I do not measure the quality of those procedures, and then compare the percentage of problematic Japanese procedures with the percentage in other countries. I do not ask why patients filed claims after some problematic procedures but not others, and compare those reasons across different countries. ${ }^{55}$

Suggestively to be sure, however, the study does pose implications for the level of malpractice claims. Those implications tie malpractice claims to the level of medical technology, and medical technology levels to the universal insurance program. The study clarifies which procedures most often generate malpractice claims; other data identify the rates at which Japanese physicians perform those procedures; and the insurance price schedule identifies the economic reason why they perform them at the rates that they do.

\subsubsection{Skewed pricing}

Consider these implications more closely. The Japanese government suppresses the price physicians can charge for various procedures. Crucially, it does not suppress prices uniformly. Instead, it suppresses them by a schedule biased against the technologically most sophisticated modern procedures. For most work, it pays a lower price than doctors charge in (for example) the United States. But for the most technologically demanding procedures, it pays an especially low price.

54 This is subject to the qualification that claimants will (precisely because of the national health insurance system) have lower claims for medical care. Wrongful death awards seem at least as high in Japan as in the United States. Damages for patients who do not die, however, will cover both medical care and lost wages. Given the insurance system, the former should be lower in Japan than in the United States.

55 I also do not purport to explain the change over time shown in Table 1 Panel A. 


\subsubsection{Rudimentary medicine}

Faced with relatively lower prices for sophisticated care than for routine care, Japanese physicians focus on routine care. Compared to their peers in the United States, they perform fewer of the complex procedures at the heart of modern medicine. They perform fewer, whether compared per capita or compared per disease-incidence.

If they wished, the large Japanese hospitals and university medical schools could perform the procedures. Technologically, they have (or could obtain) the modern equipment necessary. Professionally, they have (or could train) staff as sophisticated as those in any wealthy country. Yet compared to hospitals and physicians in the United States, they rarely perform the procedures. No matter how measured, they perform far fewer of the most complex and sophisticated procedures.

Faced with the insurance price schedule, nearly a third of Japanese physicians instead build (or inherit) and operate their own simple, private clinics. They do not (with some exceptions) buy expensive specialized medical equipment. They do not spend years in subspecialty residencies. In fact, they hardly specialize at all.

Yet of Japanese medical services, the clinic doctors supply a large fraction. They treat nearly any patient who walks in the door. Paid for outpatients by the visit, they require their patients to return time and again. Paid generously for in-patient care, they warehouse their patients for weeks on end at government expense.

\subsubsection{Implications for claiming behavior}

Just as the insurance pricing schedule affects the levels of medical technology, those technological levels in turn affect the rates at which patients file claims. As explained above, the schedule increases the amount of rudimentary care and decreases the amount of sophisticated care. The relative amounts of the two levels of care, however, necessarily also affect the number of claims patients can plausibly file.

For reasons elaborated in detail above at Section 4.4 (reasons, for the most part, not specific to Japan), the structure of the insurance focuses medical care on those procedures least likely to generate malpractice claims. As the regressions show, patients are less likely to sue the local doctors supplying the rudimentary, low-tech care. Instead, they sue the sophisticated specialists offering the most complex and invasive medical care. The Japanese national insurance reduces the quantity of sophisticated, 
complex care supplied. And in the process, it necessarily reduces the amount of malpractice litigation brought.

\subsection{Qualifications}

It is easy to overclaim. Insurance-driven technology-suppression may reduce the number of malpractice claims in Japan, but it hardly explains the entire contrast with the United States. The frequency of doctor error in the United States (relative to the frequency in Japan), for example, obviously matters too. To be sure, I have no reason to think American doctors make more mistakes than Japanese doctors_-but I have no data on point. I have no reason to think American doctors more forthrightly disclose their mistakes - but I have no data on that either.

Even more relevant, in several ways the U.S. judicial system may (the subject is obviously beyond the scope of this study) encourage patients to file meritless but extortionate claims in the name of malpractice. According to some (not all) accounts, in using civil juries U.S. courts arguably assign questions of care, causation, and damages to mistake-prone novices. Many U.S. state courts use judges who are less qualified than in Japan (on Japanese judges, see Ramseyer \& Rasmusen, 2003), and according to some accounts may bring a bias in favor of the local bar. And again according to some accounts, discovery (unavailable in Japan) further expands the scope for extortionate claims.

To date, however, scholars of Japanese of malpractice litigation have focused on the perceived faults in the Japanese judicial system. In doing so, they focus on the wrong questions, for their inquiries have been almost entirely off-base. The attorney fee schedule in Japan, for instance, does not explain the level of claiming-because the schedule does not bind. Court delays do not explain it either-because Japanese courts are fast. Low damage awards do not explain it-because Japanese courts are generous. Cultural peculiarities of Japanese society do not explain it-because patients most often sue the very doctors they most respect. And burdens of proof do not explain it-because Japanese courts impose the same burdens as American courts.

\section{CONCLUSIONS}


States and some other wealthy democracies. To date, most scholars have tried to explain the contrasts by identifying "faults" in the Japanese judicial system.

These scholars look in the wrong place. Part of the reason for the low claiming levels probably (the result is only suggestive) lies instead with the universal national health insurance program. Through the program, the Japanese government provides heavily subsidized medical care to all residents. To contain the enormous costs that such a demand subsidy would otherwise entail, it suppresses the prices it pays for most procedures. Crucially, it does not suppress prices uniformly. Instead, it suppresses most drastically the technologically most complex procedures.

These sophisticated procedures, however, are the very procedures most likely (in any wealthy economy) to generate malpractice claims. Physicians perform them in teams-increasing the transparency of the records available to the patients (or their heirs). Japanese courts hold the doctors able to perform these procedures to higher standards of care-making it easier for patients to meet their burdens of proof. The procedures are intrusive, succeed less often than ordinary medical care, and cater to higher-risk patients_resulting in more adverse events. And some of the procedures seem to demand greater attention and effort-perhaps generating more cases of actionable negligence.

Part of the reason for the lower level of malpractice claims in Japan, in short, may lie in the very level of medical technology. To restrain the cost of its universal insurance, the Japanese government has lowered the technological level of medical services its doctors provide. In the process, it has cut the number of procedures most likely (for whatever reason) to generate malpractice claims. That patients file so many claims in the United States, as William Sage (2003: 3) put it, "is largely a product of modern medicine's tremendous success in treating disease." That they file so many fewer in Japan may be, in part, a product of the way the national insurance has prevented as many people from enjoying that modern success.

\section{REFERENCES}

American Heart Association. 2008. www.americanheart.org/presenter.jhtml. Aoki, Noriaki, Kenji Uda, Sachiko Ohta, Takahiro Kiuchi, \& Tsuguya Fukui. 2008. Impact of Miscommunication in Medical Dispute Cases in Japan. Int'l J. Quality in Health Care, 20: 358-362. 
AON. 2004. Hospital Professional Liability and Physician Liability Benchmark Study Predicts Continued Loss Cost Increases in 2004. http:// findarticles.com/p/articles/mi_m0EIN/is_2004_Jan_27/ai_112583139/. Asahi shinbun shuppan. 2009. Shujutsu su de wakaru ii byoin 2009 [The Best Hospitals by Number of Operations, 2009]. Tokyo: Asahi shinbun shuppan.

Azami, Tatsuaki, \& Yoshio Nakai. 1994. Iryo kago ho [Medical Malpractice Law]. Tokyo: Seirin shoin.

Black, Bernard, Charles Silver, David A. Hyman, \& William M. Sage. 2005. Stability, Not Crisis: Medical Malpractice Claim Outcomes in Texas, 1988-2002. J. Empirical Legal Studies, 2: 207-259.

Bovberg, Randall R., \& Anna Bartow.2003. Understanding Pennsylvania's Medical Malpractice Crisis; Facts about Liability Insurance, the Legal System, and Health Care in Pennsylvania. Pew Charitable Trusts.

Campbell, John C., \& Naoki Ikegami. 1998. The Art of Balance in Health Policy: Maintaining Japan's Low-Cost, Egalitarian System. Cambridge: Cambridge University Press.

Canadian Health Services Research Foundation. 2006. Myth: Medical Malpractice Lawsuits Plague Canada. www.chsrf.co/mythbusters/html/ myth21_e.php.

CHSRF. See Canadian Health Services Research Foundation.

Comanor, William S., H. E. Frech III, \& Richard D. Miller. 2006. Is the United States an Outlier in Health Care and Health Outcomes? A Preliminary Analysis. Int'l J. of Health Care Finance \& Econ., 6: 3-23.

Cutler, David M. 2007. The Lifetime Costs and Benefits of Medical Technology. J. Health Econ., 26: 1081-1100.

Cutler, David M., \& Grant Miller. 2004. The Role of Public Health Improvements in Health Advances: The 20th Century United States. SSRN Working Paper 552307 (May 2004).

Cutler, David, Angus Deaton, \& Adriana Lleras-Muney. 2006. The Determinants of Mortality. J. Econ. Perspectives, 20(3): 97-120.

De Ville, Kenneth. 1998. Medical Malpractice in Twentieth Century United States. Int'l J. Technology Assessment in Health Care, 14: 197-211.

Ehara, Akira. 2005. Lawsuits Associated with Medical Malpractice in Japan: Rate of Lawsuits Was Very Low in Pediatrics, Although Many Children Visit Emergency Rooms. Pediatrics, 115: 1792-1793. 
Faxon, David P. 2008. Assessing Appropriateness of Coronary Angiography: Another Step in Improving Quality. Annals Internal Med., 149: 276-278. Feldman, Eric. 2009. Law, Society, and Medical Malpractice Litigation in Japan. Washington U. Global Stud. L. Rev., 8: 257-284.

Foote, Daniel. 1995. Resolution of Traffic Accident Disputes and Judicial Activism in Japan. L. Japan, 25: 19.

Frech, H. E., III. 2008. The OECD's Study on Health Status Determinants: Roles of Lifestyle, Environment, Health-Care Resources and Spending Efficiency: A Review and Analysis. Draft ms.

Fukuda, Takeshi. 2007. Activities of the Tochigi Medical Association. Japan Medical Ass'n J., 50: 264-266.

Geertz, Clifford. 1973. The Interpretation of Cultures. New York: Basic Books. Grady, Mark F. 1988. Why Are People Negligent? Technology, Nondurable Precautions, and the Medical Malpractice Explosion. Northwestern Univ. L. Rev., 82: 293-334.

—. 2009. Unavoidable Accident. Rev. L. \& Econ., 5: 177.

Guadagnoli, Edward, Mary Beth Landrum, Eric Peterson, Martin Gahart, Thomas Ryan, \& Barbara McNeil. 2000. Appropriateness of Coronary Angiography after Myocardial Infarction Among Medicare Beneficiaries. New Eng. J. Med., 343: 1460-1466.

Hagihara, Akihito, Minako Nishi, \& Koichi Nobutomo. 2003. Standard of Care and Liability in Medical Malpractice Litigation in Japan. Health Policy, 65: 119-127.

Haley, John Owen. 1978. The Myth of the Reluctant Litigant. J. Japanese Stud., 4: 359-390.

Hamasaki, Tomoko, Tadamichi Takehara, \& Akihito Hagihara. 2008. Physicians' Communication Skills with Patients and Legal Liability in Decided Medical Malpractice Litigation Cases in Japan. BMC Family Practice, 9: 43.

Hemingway, Harry, Angela Crook, Gene Feder, Shrilla Banerjee, J. Rex Dawson, Patrick Magee, Sue Philpott, Julie Sanders, Alan Wood, \& Adam Timmis. 2001. Underuse of Coronary Revascularization Procedures in Patients Considered Appropriate Candidates for Revascularization. New Eng. J. Med., 344: 645-654.

Hemingway, Harry, Ruoling Chen, Cornelia Junghans, Adam Timmis, Sandra Eldridge, Nick Black, Paul Shekelle, \& Gene Feder. 2008. Appropriateness Criteria for Coronary Angiography in Angina: Reliability and Validity. Annals Internal Med., 149: 221-231. 
Hiyama, Toru, Shinji Tanaka, Masaharu Yoshihara, Tatsuma Fukuhara, Shin'ichi Mukai, \& Kazuaki Chayama. 2006. Medical Malpractice Litigation Related to Gastrointestinal Endoscopy in Japan: A TwoDecade Review of Civil Court Cases. World J. Gastroenterology, 12(42): 6857-6860.

Inoue, Kiyonari. 2007. Yokuwakaru iryo sosho [Easy to Understand Medical Litigation]. Tokyo: K.K. Mainichi komyunikeeshonzu.

Jacobson, Peter D. 2006. Medical Liability and the Culture of Technology. In William M. Sage \& Rogan Kersh, eds., Medical Malpractice and the U.S. Health Care System, 115. Cambridge: Cambridge University Press. Kameoka, Hidehito. 2005. Minna no iryohi to seido [Everyone's Medical Costs and System]. Tokyo: PHP Kenkyujo.

Kamiya, Keiko, ed. 2007. Iryo jiko no sekinin [The Responsibility for Medical Accidents]. Tokyo: K.K. Mainichi komyunikeeshonzu.

Kato, Shintaro. 2005. Iryo kago sosho (I) [Medical Malpractice Litigation (I)]. In Kaoru Kamata, et al., eds. Minji ho III [Civil Law III], pp. 265283. Tokyo: Nihon hyoron sha.

Kinoshita, Katsuyuki. 2007. Professional Liability Insurance Program of the Japan Medical Association. Japan Medical Association J., 50: 390-396. Kodama, Yasushi. 2007. Iryo anzen [Medical Safety]. Jurisuto, 1339: 67. Kokuritsu shakai hosho jinko mondai kenkyujo, ed. 2006. Shakai hosho tokei nenpo [Social Security Statistics Annual]. Tokyo: Hoken.

Kosei rodo sho. 2005. Iryo shisetsu chosa:ge [Survey of Medical Facilities: Part II]. Tokyo: Kosei tokei kyokai.

- 2006. Kosei tokei yoran [Handbook of Health and Welfare Statistics]. Tokyo: Kosei tokei kyokai.

- 2008. Chiiki hoken iryo kiso tokei, Heisei 19 nen [Basic Medical and Insurance Statistics by Region, 2007]. Tokyo: Kosei rodo sho.

Leflar, Robert B. 2009a. The Regulation of Medical Malpractice in Japan. Clinical Orthopaedics \& Related Research, 467: 443-449.

-. 2009b. "Unnatural Deaths," Criminal Sanctions, and Medical Quality Improvement in Japan. Yale J. Health Policy L. \& Ethics, 9: 1-51.

Leflar, Robert B., \& Futoshi Iwata. 2005. Medical Error as Reportable Event, as Tort, as Crime: A Transpacific Comparison. Widener L. Rev., 12: 189-225.

Maeda, Shoichi, Noriko Sakamoto, \& Koichi Nobutomo. 2001. The Problems of Medical Malpractice Litigation in Japan: The Significant Fac- 
tors Responsible for the Tendency of Patients to Avoid Litigation. Legal Medicine, 3: 56-62.

McClellan, Mark, Barbara J. McNeil, \& Joseph P. Newhouse. 1994. Does More Intensive Treatment of Acute Myocardial Infarction in the Elderly Reduce Mortality? Analysis Using Instrumental Variables. JAMA, 272: 859-866.

Mello, Michelle M., \& David M. Studdert. 2006. The Medical Malpractice System: Structure and Performance. In William M. Sage \& Rogan Kersh, eds., Medical Malpractice and the U.S. Health Care System, pp. 11-29. New York: Cambridge University Press.

- 2008. Deconstructing Negligence: The Role of Individual and System Factors in Causing Medical Injuries. Georgetown L.J., 96: 599-623. MHWL. See Kosei rodo sho.

Miyasaka, Yuhei. 2002. JMA Professional Medical Liability Insurance Program. Japan Medical Assoc. J., 45: 407-415.

Nakajima, Kazue, Catherine Keyes, Tatsuo Kuroyanagi, \& Kozo Tatara. 2001. Medical Malpractice and Legal Resolution Systems in Japan. JAMA, 285: 1632-1640.

Nakamura, Satoshi. 2001. Iryo sosho no jitsumuteki kadai [Practical Issues in Medical Litigation]. Tokyo: Hanrei taimuzu sha.

Nakazato, Minoru, J. Mark Ramseyer, \& Eric B. Rasmusen. 2010. The Industrial Organization of the Japanese Bar: Levels and Determinants of Attorney Incomes. J. Empirical Legal Stud., 7:460-489.

National Practitioner Data Bank. 2005. 2005 Annual Report. Health Resources and Services Administration, U.S. Department of Health and Human Services.

Nihon bengoshi rengo kai. 2005. Bengoshi hakusho [Attorney White Paper]. Tokyo: Nihon bengoshi rengo kai.

Nihon iryo seisaku kiko, ed. 2007. Iryo hakusho [Medical White Paper]. Tokyo: K.K. Nihon iryo kikaku.

Normand, Sharon-Lise T., Mary Beth Landrum, Edward Guadagnoli, John Ayanian, Thomas Ryan, Paul Cleary, \& Barbara McNeil. 2001. Validating Recommendations for Coronary Angiography Following Acute Myocardial Infarction in the Elderly: A Matched Analysis Using Propensity Scores. J. Clinical Epidemiology, 54: 387-398.

NPDB. See National Practitioner Data Bank.

OECD. 2006. Medical Malpractice: Prevention, Insurance and Coverage Options. Paris: OECD. 
Ouchi, Koichi. 2005. Yasashii iryo keizaigaku [Simple Medical Economics]. Tokyo: K.K. Keiso shobo.

Peeters, Anna, Jan Barendegt, Frans Willekens, Johan Mackenbach, Abdullah Mamun, \& Luc Bonneux. 2003. Obesity in Adulthood and Its Consequences for Life Expectancy: A Life-Table Analysis. Ann. Intern. Med., 138(1): 24.

Priest, George, \& Benjamin Klein. 1984. The Selection of Disputes for Litigation. J. Legal Stud., 13: 1-55.

Ramseyer, J. Mark. 2009a. The Effect of Cost Suppression under Universal Health Insurance on the Allocation of Talent and the Development of Expertise: Cosmetic Surgery in Japan. J. Law \& Econ., 52: 497-522.

- 2009b. Universal Health Insurance and the Effect of Cost Containment on Mortality Rates: Strokes and Heart Attacks in Japan. J. Empirical Legal Stud., 6: 309-342.

- 2010. Talent Matters: Judicial Productivity and Speed in Japan. Harvard Law School, John M. Olin Center for Law \& Economics, Working Paper 663. http://papers.ssrn.com/sol3/papers.cfm?abstract_ $\mathrm{id}=1548672$.

Ramseyer, J. Mark, \& Minoru Nakazato. 1989. The Rational Litigant: Settlement Amounts and Verdict Rates in Japan. J. Legal Stud., 18: 263-290.

- 1999. Japanese Law: An Economic Approach. Chicago: University of Chicago Press.

Ramseyer, J. Mark, \& Eric B. Rasmusen. 2003. Measuring Judicial Independence: The Political Economy of Judging in Japan. Chicago: University of Chicago Press.

Reynolds, Roger A., John A. Rizzo, \& Martin L. Gonzalez. 1987. The Cost of Medical Professional Liability. JAMA, 257: 2776-2781.

Riles, Annelise \& Takashi Uchida. 2009. Reforming Knowledge? A SocioLegal Critique of the Legal Education Reforms in Japan. Drexel L. Rev., 1: 3-51.

Sage, William M. 2003. Understanding the First Malpractice Crisis of the 21st Century. In Alice G. Gosfield, ed., 2003 Health Law Handbook, 1. St Paul: West.

Saiko saibansho jimusokyoku, ed. 2004. Shiho tokei nempo: Minji gyosei hen [Annual Report of Judicial Statistics: Civil and Administrative Cases]. Tokyo: Hoso kai. Available at www.courts.go.jp.

Sasao, Shogo, Toru Hiyama, Shinji Tanaka, Shinichi Mukai, Masaharu Yoshihara, \& Kazuaki Chayama. 2006. Medical Malpractice Litigation 
in Gastroenterological Practice in Japan: A 22-Yr Review of Civil Court Cases. Am. J. Gastroenterology, 101: 1951-1953.

Sawa, Rintaro. 2008. A Healthcare Crisis in Japan: Criminalizing Medical Malpractice. Japan Medical Association J., 51: 235-241.

Sezai, Yukiyasu, Yukihiko Orime, \& Saeki Tsukamoto. 2007. Coronary Artery Surgery Results 2005 in Japan. Ann. Thoracic \& Cardiovascular Surgery, 13(3): 220-223.

Shiho tokei. See Saiko saibansho.

Shimada, Yasuhiro, \& Yoshio Kato. 1994. Anesthesia Mortality and Morbidity in Japan: A Study of Lawsuit Cases. J. Anesthesia, 8: 1-5.

Shukan Asahi, ed. 2008. Shujutsu su de wakaru ii byoin [Good Hospitals, Identified by the Number of Operations]. Shukan Asahi, Feb. 2008.

Sloan, Frank A., \& Lindsey M. Chepke. 2008. Medical Malpractice. Cambridge: MIT Press.

Sonpo Japan. 2008. Disclosure filings required under securities regulation. Studdert, David M., Michelle M. Mello, Atul A. Gawande, Tejal K. Gandhi, Allen Kachalia, Catherine Yoon, Ann Louise Puopolo, \& Troyen A. Brennan. 2006. Claims, Errors, and Compensation Payments in Medical Malpractice Litigation. New England J. Medicine, 354: 2024-2033. Takeda, Norio. 2008. The Medical Association Needs the Power from HospitalBased Physicians and Hospital-Based Physicians Also Need the Power from the Medical Association. Japan Medical Ass'n J., 51: 204-206.

Takimoto, Toyomizu. 1994. Zusetsu: Nihon no songai hoken [Illustrated: Japan's Liability Insurance]. Tokyo: Keizai shoho.

Toba, Ken. 2005. Nihon jin no heikin chi [Japanese Averages]. Tokyo: Seikatsu joho sentaa.

Tokyo chiho saibansho iryo sosho taisaku iinkai. 2003. Tokyo chisai iryo shuchubu ni okeru iryo sosho no shinri no jitsujo ni tsuite [The Reality of the Investigations into Medical Malpractice Litigation in the Tokyo District Court Specialized Medical Section]. 1105 Hanrei taimuzu 34.

Trebilcock, Michael J., Donald N. Dewees, \& David G. Duff. 1990. The Medical Malpractice Explosion: An Empirical Assessment of Trends, Determinants, and Impacts. Melbourne U. L. Rev., 17: 539-565.

Uchida, Takashi. 2007. Saiken kakuron [Personal Rights: Detailed Matters]. 2nd ed. Tokyo: University of Tokyo Press.

Ueda, Kazutaka. 2007. Jitsumu Iryo kago sosho [Practical: Medical Malpractice Litigation]. Tokyo: Minji ho kenkyukai. 
Vidmar, Neil, Paul Lee, Kara MacKillop, Kieran McCarthy, \& Gerald McGwin. 2005. Uncovering the "Invisible" Profile of Medical Malpractice Litigation: Insights from Florida. DePaul L. Rev. 54: 315-356.

Weiler, Paul C., Howard H. Hiatt, Joseph P. Newhouse, William G. Johnson, Troyen A. Brennan, \& Lucian L. Leape. 1993. A Measure of Malpractice: Medical Injury, Malpractice Litigation, and Patient Compensation. Cambridge: Harvard University Press.

Wheat, Kay. 2005. Is There a Medical Malpractice Crisis in the UK? J. L. Med. \& Ethics, 33: 444-455.

World Health Organization. 2008. Global Database on Body Mass Index. www.who.int/bmi.

Yamana, Manabu \& Hiroshi Oshima. 2003. Saikin no iryo sosho no doko to shinri no jitsujo [The Reality of the Recent Direction in Investigations into Medical Malpractice Litigation]. Jiyu to seigi, Feb. 2003, at 14.

Yamashita, Noritaka. 2008. Ishi baisho sekinin hoken keiyaku ni okeru hoken jiken ni kansuru ichikosai [Some Thoughts on Insurance Cases under Insurance Contracts for Physician Liability. Songai hoken kenkyu, 69 (4): 1.

Yashiro, Naohiro, Reiko Suzuki, \& Wataru Suzuki. 2006. Evaluating Japan's Health Care Reform of the 1990s and Its Efforts to Cope with Population Aging. In Wise \& Yashiro, Health Care Issues in the United States and Japan. Chicago: University of Chicago Press.

Yasunaga, Hideo. 2008. Legal Intervention Against Medical Accidents in Japan. Risk Management \& Health Care Policy, 2008: 1, 39-42.

Yomiuri shinbun sha, ed. 2008. www.yomiuri.co.jp/iryou/medi/jitsuryoku.

Yoshikawa, Kosaburo, \& Hiroshi Makabe. 2006. Iryo jiko sosho ni okeru wakai jirei no kenkyu [A Study of Settled Cases in Medical Malpractice Litigation]. Tokyo: Gendai jimbunsha. 